\title{
ABERTURA DA PRIVACIDADE E O SIGILO DO HIV/AIDS NAS EQUIPES DO PROGRAMA SAÚDE DA FAMÍLIA DE UMA UNIDADE BÁSICA DE SAÚDE DO MUNICÍPIO DE SÃO PAULO
}

Dissertação apresentada à Escola de Enfermagem da Universidade de São Paulo para obtenção do título de Mestre em Enfermagem.

Área de Concentração:

Enfermagem em Saúde Coletiva

Orientadora:

Prof ${ }^{a}$. Dra . Lúcia Y. Izumi Nichiata 



\section{DEDICATÓRIA}

Aos meus queridos pais, Claudia e Pedro, pelo carinho, apoio e auxilio durante o desenvolvimento deste trabalho.

A toda a minha família em especial aos meus queridos avós maternos, Teresa $\boldsymbol{e}$ Tavares, e aos meus avós paternos, Cida e Zelão, por me apoiarem sempre e estarem presentes na minha vida.

A minha madrinha querida Meia que esteve comigo sempre, me apoiando em todos os momentos.

Ao Rafael Fagundes Matheus, querido companheiro, sempre pronto para me ajudar em todos os momentos. Obrigada pelo estímulo de dizer para sempre ir em frente, pela compreensão nos momentos difíceis, por estar comigo nos momentos bons e ruins de toda a nossa história.

A família Fagundes, em especial a Eliana e Cyro, pelo apoio, estímulo e valorização do meu trabalho.

In memorian, a minha querida tia Flávia Tavares, que continuará presente em nossa família. 


\section{AGRADECIMENTOS}

À prof ${ }^{a}$. Dr ${ }^{a}$. Lúcia Y. Izumi Nichiata pela orientação desde a graduação. Obrigada por acreditar na construção desta dissertação, pelas horas extras de trabalho e pelo estímulo de nunca desistir.

Á prof ${ }^{a}$. Dr ${ }^{a}$ Renata Takahashi e a prof ${ }^{a}$. Dr ${ }^{a}$ Eunice Nakamura por aceitarem o convite participarem da banca examinadora. Obrigada pelos apontamentos $e$ contribuições.

À prof ${ }^{a}$. Dr ${ }^{a}$. Elma Lourdes Campo Pavone Zoboli pela contribuição teórica que fez parte do desenvolvimento deste trabalho.

Aos funcionários da Biblioteca Wanda de Aguiar Horta, pelo suporte durante o desenvolvimento deste trabalho.

Aos funcionários da Secretaria de Pós-Graduação, especialmente a Silvana, pelo incentivo e orientação.

À gerente da UBS Vila Penteado, Dr ${ }^{a}$. Yoshimi Ito Villanova, que além de abrir as portas da UBS para a realização da coleta de dados, contribuiu para a descrição do cenário de estudo.

À todos os funcionários da UBS Vila Penteado, especialmente aos médicos, enfermeiras, auxiliares de enfermagem e agentes comunitários, que se disponibilizaram amavelmente a participar desse estudo.

À Dra. Valéria T. Bosco, gerente da UBS Dr. Augusto LA Galvão, que me apoiou e me ajudou em momentos importantes.

À todos os funcionários da UBS Dr. Augusto LA Galvão que fazem parte do meu dia-a-dia, especialmente a minha querida equipe de trabalho. 
À Tatiana Pegoretti que dizia sempre para não desistir. Obrigada por disponibilizar tempo para me ajudar nos momentos difíceis.

Aos antigos colegas de trabalho que de alguma forma contribuíram para a continuidade deste trabalho.

À Mônica de Carvalho pelo auxílio na coleta de dados.

Ao Gustavo Mello Camarão pela grande ajuda na compreensão da língua inglesa.

À Prof ${ }^{a}$ Isabel Celeste de Barros Navarausckas pelo carinho e pela revisão de português.

Às amigas de tantos anos, Séfora Santos e Carolina Marçal, e a todos os meus amigos e amigas. Obrigada pelo apoio e pela compreensão.

Às amigas da graduação que incentivaram a escolha pelo caminho da pesquisa e pelos momentos de movimento estudantil. 


\section{RESUMO}

Abdalla FTM. Abertura da privacidade e o sigilo do HIV/AIDS nas equipes do Programa Saúde da Família de uma Unidade Básica de Saúde do município de São Paulo [dissertação]. São Paulo: Escola de Enfermagem, Universidade de São Paulo; 2007.

Desde a identificação das primeiras pessoas com aids vêm ocorrendo mudanças no perfil da epidemia. Acometendo inicialmente homens, adultos com alta escolaridade e com práticas homossexuais, passou a atingir cada vez mais os jovens, os grupos sociais de maior exclusão social, as pessoas com práticas heterossexuais e as mulheres. Observa-se crescimento de casos em mulheres a partir da década de 90, embora proporcionalmente o número de casos seja ainda maior em homens. Até novembro de 2000, do total de 196016 casos de aids notificados no Brasil, um quarto era do sexo feminino. Após o diagnóstico da infecção pelo HIV, as mulheres enfrentam dificuldades das mais variadas formas, desde aquelas relacionadas à infecção e ao adoecimento, ao tratamento e aos cuidados diários, até aquelas referidas ao campo afetivo-relacional. Dado que a doença é envolta em preconceito, estigma que podem levar a discriminação há preocupação das mulheres com o "segredo" da infecção pelo HIV. Considerando isto, o Programa Saúde da Família (PSF) pode incluir ações que desenvolvam habilidades de busca e recepção de apoio social, fortalecimento de vínculos familiares e sociais na assistência e convivência com as pessoas acometidas pelo HIV/AIDS. O PSF convergindo para a promoção da qualidade de vida das pessoas e de seu ambiente pode intensificar as ações de promoção à saúde e prevenção do HIV. Desta forma, entende-se que, considerando a autonomia da usuária, a abertura da privacidade pela usuária pode auxiliar na resposta às necessidades de saúde pelas equipes de PSF. As discussões sobre os conflitos que os profissionais de saúde do PSF encontram no seu cotidiano e que envolvem a manutenção da privacidade e sigilo das informações das usuárias, na perspectiva da Bioética, especialmente na questão do HIV/AIDS, são objetos do presente estudo. Seus resultados podem servir como subsídios para a reflexão das práticas do PSF e conseqüentemente para a melhoria da qualidade da assistência em saúde. Este estudo teve como objetivo discutir as situações que envolvem questões de privacidade e sigilo das informações nas experiências de assistência às mulheres portadoras de HIV/AIDS, vivenciadas pelas equipes do PSF. Trata-se de um estudo qualitativo descritivo, exploratório, na qual foram utilizadas as metodologias de grupo focal e entrevista semi estruturada. Foi realizada numa Unidade Básica de Saúde que opera com modelo de PSF no município de São Paulo. Foram coletadas as falas de dois grupos focais com agentes comunitários de saúde (ACS) e 25 entrevistas individuais com enfermeiros, médicos e auxiliares de enfermagem. Os depoimentos foram analisados segundo Bardin e organizados nos temas: a) a revelação do diagnóstico de HIV para a usuária; b) acolhimento e vínculo na abertura da privacidade; c) a revelação do diagnóstico de HIV aos membros da equipe de PSF e, d) discussão em equipe e o sigilo das informações. Verificou-se que os profissionais do PSF tomam conhecimento sobre o diagnóstico do HIV pela própria usuária, familiares, vizinhos, ACS ou outro membro da equipe e profissionais de saúde dos serviços de referência, além do prontuário e dos resultados de exames. A mulher revela seu diagnóstico de HIV, abrindo sua privacidade quando há confiança e vínculo na relação usuária- 
profissional. Os profissionais buscam assegurar o sigilo referente ao diagnóstico do HIV. A abertura da privacidade da informação possibilita a discussão das necessidades de saúde da usuária e o planejamento das ações pelas equipes de PSF.

Palavras-chave: HIV, aids, privacidade, comunicação sigilosa, saúde da família. 


\begin{abstract}
Abdalla FTM.Opening of Privacy and Secrecy of HIV/AIDS in the Family's Health Program team in a Health Basic Unit from the city of Sao Paulo. São Paulo: Escola de Enfermagem, Universidade de São Paulo; 2007.

Ever since the first cases of Aids were identified, there has been a change on the profile of the disease. In the beginning its was predominantly seen in well-informed adult males with homosexual practices, then changing to a much younger group, with less access to information and also women. After the 90 `s you will see a significant increase in the number of cases in women although men are still the most affected. In November of 2000, there were 196016 cases of Aids identified in Brazil, where 25\% were females.After diagnosis, women would face many difficulties such as things related to the infection and illness itself, treatment and everyday care and also personal relationships. Those infected with Aids, are many times worried about discrimination and stereotyping what makes them keep it secret. The objective of the Family's Health Program (PSF) is to make people seek help to strengthen social and family links and also learn to live and socialize with other people with HIV/AIDS. The PSF promotes quality of life, healthy practices and HIV prevention. Patients disclose more information and that helps PSF professionals find more answers to the healthcare questions they might have. That creates another problem that refers to confidentiality and bioethics which are also subjects of the present study. Its Results can increase awareness about the practices of PSF and with that, improve the quality of healthcare assistance. The objective of this study is to discuss privacy and confidentiality of information related to women infected with HIV/AIDS, that were assisted by PSF teams. It is a descriptive, qualitative, exploratory study that focused on focal groups and semi structured interview methods. It was done at a Health Basic Unit that operates using a PSF model in São Paulo. Data was collected from two groups with communitarian agents of health (ACS) and also 25 different interviews with nurses, tecnics, and doctors. Testimonies were analyzed according to Bardin and put into different categories: a) Revealing HIV diagnosis to users of PSF; b) Welcoming and using bonding experiences when talking about the subject; c) Revealing HIV diagnosis to the members of PSF team; d) Team discussion and confidentiality of information.We found that PSF professionals learn about the diagnosis through the patients themselves, their families, ACS and other healthcare professionals and of course, official test results. The women patients feel comfortable to talk about their HIV diagnosis when there is trust in the healthcare professional - user relationship. Professionals always try to ensure confidentiality of information about the diagnosis. This information enables professionals to talk about the health condition of the users and help PSF team members set up a plan of action.
\end{abstract}

KEY WORDS: HIV, Aids, privacy, confidential communication, family health. 


\section{SUMÁRIO}

\section{APRESENTAÇÃO}

\section{INTRODUÇÃOO}

1.1 O panorama do HIV/AIDS entre as mulheres no município de São Paulo

1.2 O Programa Saúde da Família e a assistência às mulheres infectadas pelo HIV.

2 OBJETIVO

\section{METODOLOGIA}

3.1 QUADRO TEÓRICO-METODOLÓGICO

Bioética, Autonomia, Privacidade e Sigilo

3.2 Cenário de estudo 25

$\begin{array}{ll}3.3 \text { Sujeitos da Pesquisa } & 28\end{array}$

3.4 Coleta de Dados 28

3.5 Instrumentos de coleta de dados $\quad 30$

3.6 Análise dos dados 31

3.7 Aspectos Éticos $\quad 32$

\section{RESULTADOS E DISCUSSÃO}

4.1 Caracterização dos sujeitos de pesquisa 34

4.2 A Revelação do diagnóstico do HIV para a usuária 37

4.3 Acolhimento e Vínculo na abertura da privacidade 46

4.4 A Revelação do diagnóstico do HIV aos membros da equipe de PSF 57

4.5 Discussão em equipe e o sigilo das informações 65

5 CONSIDERAÇÕES FINAIS

6 REFERÊNCIAS BIBLIOGRÁFICAS 82

ANEXOS

ANEXO 01

ANEXO $02 \quad 90$

ANEXO $03 \quad 92$ 


\begin{abstract}
APRESENTAÇÃO
A motivação para o desenvolvimento deste estudo sobre a temática aids partiu de minha experiência enquanto aluna de iniciação científica na graduação da Escola de Enfermagem da Universidade de São Paulo em 2003. Na ocasião, ao descrever a distribuição da mortalidade por doenças transmissíveis de notificação compulsória, segundo diferentes região do município de São Paulo, verificou-se que a aids era a primeira causa de morte dentre todas as doenças, embora venha se observando uma diminuição da taxa de mortalidade por este agravo, provavelmente em função da ampliação da oferta de ambulatórios especializados e disponibilização dos antiretrovirais (ARV). A maior sobrevida das pessoas vivendo com o vírus tem sido uma realidade, e são novos os desafios colocados, particularmente no que diz respeito ao enfrentamento das necessidades de saúde desta população pelos profissionais de saúde.

O ingresso, em 2005, como enfermeira em uma Unidade Básica de Saúde que opera com o modelo assistencial Programa Saúde da Família (PSF), estimulou-me a discutir sobre como as equipes de saúde vêm fazendo o reconhecimento e o enfrentamento das necessidades de saúde das pessoas infectadas pelo HIV, uma doença envolta nas questões relacionadas ao medo do preconceito e estigma. Mais especificamente, discutir como as equipes de saúde têm lidado com a questão da abertura da privacidade e o sigilo das informações sobre HIV/AIDS.

Por meio deste estudo, espera-se obter subsídios para contribuir com a melhoria da qualidade da assistência aos indivíduos com HIV/AIDS e familiares, particularmente pelas equipes do PSF.
\end{abstract}




\section{INTRODUÇÃO}

\subsection{O panorama do HIV/AIDS entre as mulheres no Brasil e no município de São Paulo.}

No início da década de 80, a humanidade encontrou o grande desafio de enfrentar a pandemia da aids, doença causada pelo vírus da imunodeficiência adquirida e que hoje ocupa lugar de destaque entre os principais problemas de saúde no mundo. Ao descrever a trajetória da aids através do número absoluto de casos, observa-se que nos vinte e seis primeiros anos da epidemia, de 1980 a 30 de julho de 2006, o Brasil notificou 433067 casos de aids (Brasil, 2006).

Em relação à distribuição geográfica, no início da epidemia até a primeira metade da década passada, a aids se concentrava nas grandes metrópoles brasileiras e nos anos subseqüentes disseminou-se para as outras regiões do país num processo identificado como interiorização da epidemia. Nesse processo, 33340 municípios brasileiros (60\% do total de municípios) têm registro de pelo menos um caso, e a cada ano são notificados em média 15 mil brasileiros com a doença (Teixeira, 2002).

O Estado de São Paulo, com cerca de 38,6\% do total de notificações realizadas em todo país até 30 de julho de 2006, é aquele com maior número de casos. No mesmo período, a capital do estado é a cidade que mais apresentou casos notificados por aids (Brasil, 2006; São Paulo, 2006).

No município de São Paulo, observa-se crescimento no número de casos até o ano 2000, a partir então se observa estabilização da incidência até 2005 (São Paulo, 2005). A diminuição do número de casos foi maior para os homens do que para as mulheres, chegando a representar a primeira causa de morte entre mulheres na faixa etária de 20 a 34 anos, na cidade de São Paulo (Santos et al, 2002). 
Desde a identificação das primeiras pessoas com aids, algumas mudanças no perfil da epidemia têm sido identificadas. Acometendo inicialmente homens, adultos com alta escolaridade e com práticas homossexuais, passou a atingir cada vez mais os jovens, se alastrando nos grupos sociais de maior exclusão social e com práticas heterossexuais (Parker e Camargo Jr, 2000).

A disseminação do agravo entre homens que fazem sexo com homens ocupou, na década de $80,45 \%$ de todos os casos notificados por HIV/AIDS no Brasil. Em 2000 passou a representar 21,8\% da participação desta categoria, aumentando a exposição heterossexual (Reis, 2004).

Em pessoas com práticas heterossexuais, o aumento da incidência de aids tem sido acompanhado pelo crescimento de casos de aids em mulheres a partir da década de 1990, embora proporcionalmente o número de casos seja ainda maior entre os homens. Constata-se o impacto da epidemia nas mulheres brasileiras na redução da proporção de homens e mulheres, que passou de 30/1 em 1987, a 7/1 em 1990 e para 3/1 em 1996 e no aumento no número de casos notificados entre as mulheres, observado no incremento de $71 \%$ entre 1980 e 2000, cerca de nove vezes mais do que o observado entre os homens. Até novembro de 2000, do total de 196016 casos de aids notificados no Brasil, um quarto eram mulheres (Brasil, 2000).

No processo saúde-doença na condição da infecção do HIV existem particularidades específicas da mulher que a diferem do homem, como os fatores biológico e sociais, que favorecem a infecção pelo vírus e o desenvolvimento da doença. Entre as particularidades destacam-se as diferenças anatômicas, a maior concentração do vírus no sêmen do que na mucosa vaginal, as inflamações e irritações bem como a vulnerabilidade para as doenças sexualmente transmissíveis, a desigualdade social, as questões de gênero, a falta de percepção de risco, principalmente em mulheres envolvidas em relacionamentos estáveis (GarcíaSanches, 2004; Villela, 1996).

A imagem da mulher como mãe-esposa-mulher, desatrelada do perfil vinculado aos grupos de risco, serviu como uma proteção ao HIV, mas que não impediu a disseminação do HIV na população feminina (Ferreira, 2007).

Em relação à mortalidade por aids, com a introdução de medicamentos ARV na rede de serviços de saúde especializados e com a descentralização do 
atendimento, que possibilita um diagnóstico mais precoce e a intervenção adequada sobre as infecções oportunistas, vem se observando diminuição nas taxas. Para os homens é mais nítida a diminuição, que passa a partir de 1996, de 14,4 para 8,4 por 100 mil habitantes em 2004. Já entre as mulheres, embora haja pequena diminuição na taxa de mortalidade um ano após a redução verificada nos homens - em 1997 passou de 4,1 para 3,9 (por 100 mil habitantes) em 2004 -, ainda pode-se dizer que se mantém o crescimento da mortalidade entre as mulheres (Brasil, 2005).

A diminuição da mortalidade, alterando consideravelmente a sobrevida das pessoas acometidas pelo vírus, pode ampliar não apenas sua expectativa de vida, como também a qualidade de vida. No entanto, diferentemente dos homens, as mulheres acometidas pelo HIV, segundo analisam Santos et al. (2002), têm o seu diagnóstico realizado tardiamente, quando a infecção encontra-se mais avançada. Dessa forma, para as mulheres, o acesso ao tratamento ocorre em estágios mais adiantados da doença.

Além disso, após o diagnóstico da infecção pelo HIV, as mulheres enfrentam dificuldades das mais variadas formas, desde aquelas relacionadas diretamente à infecção e ao adoecimento, ao tratamento e aos cuidados diários, até aquelas referidas ao campo afetivo-relacional. Segundo analisa Tunala (2002), estas últimas são as principais fontes cotidianas de estresse indicadas pelas mulheres portadoras do vírus, derivadas muitas vezes do estigma associado ao HIV, gerando sentimentos de medo, solidão e abandono.

A preocupação com o "segredo" da infecção pelo HIV, segundo analisa Galvão (2004), “muitas vezes é auto-imposta pelo medo que o portador ou doente tem de, ao tornar conhecido seu diagnóstico, ficar sujeito a preconceitos e estigmatização”. Não entrar em contato com a revelação do seu diagnóstico, muitas vezes, é uma forma de evitar o sofrimento. Não relatar sua doença é mais uma maneira de não se identificar Os recurso utilizado pelas mulheres para manter oculta sua condição de portadora serve também para proteger os familiares e filhos da rejeição e discriminação que possam sofrer. Muitas mulheres omitem a doença da família, dos amigos e até dos próprios parceiros (Pereira, 2001).

Lopes e Fraga (1998) verificaram que, quando comunicadas sobre a condição de soropositividade ao HIV, as pessoas reagem expressando não aceitação e 
inconformismo com sua nova condição. Além disso, identificaram auto-isolamento, fuga dos problemas e medo: de revelar o diagnóstico para amigos; de contaminar outras pessoas; das doenças oportunistas; de morrer; de mudar a própria aparência; da solidão e do preconceito. Sobre a atividade sexual, os portadores dos vírus relataram que manter o segredo dá uma idéia de "normalidade” à vida e que a idéia de divulgação do diagnóstico é fonte de angústia. Os autores relatam que a condição de soropositividade traz instabilidade à vida das pessoas, dada à intensidade das mudanças que acarreta.

No estudo de Ferreira (2007), observa-se que, quando a mulher conta sobre seu diagnóstico e recebe apoio, há abertura da privacidade aos familiares e aos profissionais. Porém quando as mulheres contam sobre seu diagnóstico e não têm apoio, sofrem rejeição na família e demoram a voltar a ter confiança nas pessoas.

Segundo afirma Tunala (2002), é necessário que os serviços incorporem intervenções que promovam a saúde das pessoas acometidas pelo HIV, entre outras coisas, incluam ações que desenvolvam habilidades de busca e recepção de apoio social (amigos, parentes, instituições, serviços da comunidade e outras), bem como capacidade de fazer negociações nas diversas relações.

Para Ferreira (2007), é necessário que os serviços de saúde que operam com o modelo de Programa Saúde da Família (PSF) promovam ações relacionadas à discussão de questões pertinentes ao viver com HIV/AIDS a fim de diminuir os preconceitos existentes na comunidade.

Considerando isto, a rede de atenção à saúde deve estar preparada para acolher as mulheres acometidas pelo HIV, de forma mais ampla, para além do manejo clínico da infecção. Especialmente no que diz respeito a auxiliá-las na reorganização do seu cotidiano e reestruturação da vida, naquilo em que sua condição de portadora modifica o convívio social, o trabalho, as relações familiares e sociais. Concretamente, segundo Takahashi et al (1998), são necessários mecanismos para promover maior autonomia e capacidade de enfrentamento para mulheres. 


\subsection{O Programa Saúde da Família e a assistência às mulheres infectadas pelo HIV.}

No Brasil, o Sistema Único de Saúde, política social pública de atenção à saúde, estabelece que as unidades de saúde devem ser capazes de dar atenção integral à saúde dos cidadãos, pressupondo que as atividades de assistência, promoção e prevenção às doenças sexualmente transmissíveis e aids devam ser articuladas entre si, compatíveis com as necessidades da população e asseguradas pelo sistema (Brasil, 2005). Dessa forma, cabe aos municípios organizar a rede de atenção ao HIV/AIDS nos seus territórios de abrangência.

As primeiras ações na cidade de São Paulo voltadas à questão da aids foram iniciadas no âmbito da Secretaria Estadual da Saúde de São Paulo, em 1983, antes mesmo da conformação do Programa Nacional de DST/AIDS. Estas ações diziam respeito à organização, coordenação e estruturação das atividades de diagnóstico, controle e orientações em relação ao agravo; estabelecimento da vigilância epidemiológica e divulgação das informações. Criou-se o primeiro Centro de Referência e Treinamento em Doenças Sexualmente Transmissíveis e AIDS (CRTDST/AIDS) que, juntamente com o Instituto de Infectologia Emílio Ribas, respondia pelo atendimento da demanda de doentes de aids no Estado. (Guerra, 1993; Nichiata, 1995).

No âmbito da Secretaria Municipal de São Paulo, a discussão para implantação das ações programáticas iniciou-se por volta de 1987, concretizando o Programa Municipal de Prevenção e Controle de DST/AIDS. Como primeiras iniciativas, criaram-se em 1989 o Centro de Testagem e Aconselhamento (CTA), o CTA Henfil, na região central da cidade, e o Centro de Referência de DST/AIDS Herbert de Souza, o CR Betinho, em Sapopemba, zona leste da cidade (São Paulo, 2003).

O CTA fornece informações, aconselhamento, diagnóstico da infecção pelo HIV, oferecidas, de forma anônima e sigilosa, à população em geral e a grupos vulneráveis. Já as unidades assistenciais, Centro de Referência (CR), Serviço de 
Assistência Especializada (SAE) e Ambulatórios de Especialidades (AE), distinguem-se pelo seu grau de complexidade, têm como finalidade acolher pessoas afetadas pelo HIV/AIDS que necessitam de atendimento ambulatorial ou internaçãodia para uso de medicação específica, em regime de hospital-dia. Há ainda neste serviço a modalidade de atendimento domiciliar terapêutico e ações de prevenção.

Em 1993 o Programa Municipal inicia um processo de sensibilização e capacitação da rede, particularmente no âmbito da Atenção Básica, para a realização descentralizada de ações voltadas ao diagnóstico precoce da infecção e encaminhamento dos portadores para os demais níveis de assistência (Gryschek, 2001).

A consolidação do Programa Municipal deve ser entendida dentro do contexto mais amplo da vida política na cidade. Esse período de ampliação dos serviços de saúde voltados ao HIV/AIDS corresponde ao período no qual houve uma mudança estrutural de toda a rede de assistência à saúde geral realizada pelo serviço público municipal, com a implantação do Plano de Assistência à Saúde (PAS), de 1993 a 2000. O PAS era pautado na ênfase assistencial e executado por um grupo de cooperativas privadas pagas através de recursos públicos, sem comprometimento com a manutenção dos serviços de Saúde Pública (São Paulo, 2003). As unidades básicas passaram a atender à semelhança de prontos-atendimentos, tendo como característica o financiamento dos serviços per capita. As consultas médicas foram privilegiadas, em detrimento de atividades realizadas por outros profissionais, como ações de prevenção de doenças e promoção da saúde, levando à desvalorização de muitas atividades programáticas, como a atenção aos portadores de hanseníase, tuberculose e aids (Guerra, 1993).

Na implementação do PAS, os serviços de DST/AIDS permaneceram na administração direta da Secretaria Municipal (São Paulo, 2003). Isolados da política oficial, os serviços se multiplicaram e passaram a totalizar 23, sendo cinco COAS, 15 CR (que levavam esse nome, mas exerciam a função real de ambulatórios especializados em DST/ AIDS) e três laboratórios especializados (Mesquita, Turienzo; 2003). Segundo Mesquita e Turienzo (2003), esta ampliação no número de serviços de diagnóstico e assistência ao HIV/AIDS se deu devido à captação de recursos do Banco Mundial, repassados à Coordenação Nacional de DST/AIDS e 
para a Secretaria Municipal de Saúde de São Paulo. Além disso, outro fator que pode explicar é a disponibilidade de locais pra o atendimento de DST/AIDS, dado que o PAS não os assumiu em sua prioridade de atendimento e o grande contingente de profissionais, funcionários da Secretaria Municipal que não aderiram ao PAS e que passaram a se envolver com o atendimento aos portadores de HIV/AIDS.

O PAS encerrou-se em 2000, e em 2001 a Secretaria Municipal da Saúde de São Paulo passou a ter a gestão plena da rede de assistência à saúde na cidade. Atualmente a assistência para os portadores de HIV/AIDS no município de São Paulo é realizada por meio das seguintes unidades: centros de testagem e aconselhamento (CTA), centros de prevenção e assistência (CPA), serviços de assistência especializada (SAE), centros de referência em DST/AIDS (CR) e ambulatório de especialidades (AE). Esses serviços são integrados ao SUS e, portanto, oferecidos gratuitamente, estão disponíveis para testes, consultas, orientações de prevenção e tratamento das DST como, por exemplo, sífilis, cândida, gonorréia, HPV, HIV/AIDS e hepatite (São Paulo, 2004).

De acordo com as diretrizes da Coordenação Nacional de DST/AIDS, conformam-se diferentes níveis de atenção do Sistema de Saúde com vistas à prevenção e controle da infecção. Em virtude da complexidade que a infecção assume, em termos sociais e de tratamento, com a necessidade de recorrer a controles laboratoriais específicos que exigem manejo complexo e fluxo organizado, o acompanhamento das pessoas já infectadas pelo vírus HIV deve ser dar no âmbito de ambulatórios especializados (São Paulo, 2003).

No âmbito da Atenção Básica, especialmente no caso de mulheres, existe um conjunto de ações voltadas à identificação de grupos vulneráveis ao HIV/AIDS que incluem o oferecimento de testes sorológicos para detecção do vírus e realização de atividades de promoção à saúde e prevenção da infecção. São ações que estão inseridas nas atividades previstas na área programática Saúde da Mulher, tais como, consulta de pré-natal; realização do exame preventivo do câncer de colo uterino; vigilância dos exames laboratoriais de rotina; realização de grupos educativos que discutem as questões de prevenção das doenças transmissíveis e aids; grupos de planejamento familiar. 
Em 1994, o Ministério da Saúde adotou a estratégia PSF para promover a integração e a organização das ações de saúde em territórios definidos, com a finalidade de propiciar o enfrentamento e a resolução de problemas identificados no nível local. O PSF preconiza a articulação de saberes e práticas com diferenciados graus de complexidade tecnológica, integrando distintos campos de conhecimento e desenvolvendo habilidades e mudanças de atitudes nos profissionais envolvidos (São Paulo, 2003).

Segundo Souza (2001), o PSF vem assumindo relevância no discurso político, institucional e social no âmbito nacional com a alocação de recursos e dispositivos de financiamento. Nesse sentido, o PSF propicia condições favoráveis ao estabelecimento de um novo patamar de relacionamento entre profissionais, gestores e família, de modo a garantir o princípio da integralidade (Gomes \& Pinheiro apud Pinheiro, 2001). A integralidade refere-se à interação entre os sujeitos envolvidos nas práticas de assistência à saúde nos diferentes níveis de atenção à saúde.

O documento das diretrizes gerais do Ministério da Saúde define que as Unidades Básicas de Saúde da Família devem trabalhar com a definição de um território de abrangência sob sua responsabilidade e cada equipe de PSF deve responder por cerca de 600 a 1000 famílias, em média 3.450 pessoas. A equipe mínima é composta por um médico, um enfermeiro, um a dois auxiliares de enfermagem e de cinco a seis agentes comunitários (ACS) (Brasil, 2001).

O PSF assume um conceito ampliado de Atenção Básica, que avança em direção a um sistema de saúde integrado que converge para a promoção da qualidade de vida das pessoas e de seu ambiente (Fortes e Zoboli, 2003). Pode, portanto, intensificar as ações de promoção à saúde e prevenção do HIV, ao mesmo tempo em que reforça, junto às pessoas afetadas, seus direitos humanos e civis (São Paulo, 2003).

O PSF no Município de São Paulo teve seu início com o Programa Qualis (Qualidade Integral à Saude) em Itaquera, em 1996, e Parque São Lucas, Sapopemba e Vila Nova Cachoeirinha, em 1997.

A reorganização da Atenção Básica pela estratégia do PSF amplia e aprofunda a dimensão ética das práticas em saúde presentes no SUS, pois sua efetivação não se resume a uma nova configuração da equipe tecno-assistencial, mas 
a um novo processo de trabalho marcado por uma prática ética, humana e vinculado ao exercício da cidadania (Zoboli e Fortes, 2004). É por meio do PSF que as formas de atendimento no quotidiano concretizam ações de saúde que permitem estreitar relações entre usuários e profissionais de saúde. Para Silva (1998), o vínculo e a responsabilidade (vínculo entre equipe de PSF e família), a resolutividade (resolver necessidades de saúde dos usuários e famílias) e o acolhimento (a capacidade da equipe de solidarizar-se com as necessidades das famílias) são três noções importantes nos serviços de saúde da família. O acolhimento e o vínculo são como diretrizes operacionais para a materialização do SUS e são avanços importantes na reorganização dos serviços.

Segundo Matumoto (1998), o encontro entre o trabalhador e o usuário traz à tona as necessidades de ambos: o(s) motivos(s) da procura do usuário ao serviço de saúde, e as necessidades do profissional que o atende. Com esse novo modelo de assistência destaca-se o acolhimento como ato ou momento de relacionamento entre o usuário e o profissional, no qual o usuário coloca suas necessidades e interesses na forma de problemas que devem ser acolhidos como objeto de trabalho do serviço de saúde.

No âmbito da epidemia de HIV/AIDS, as ações são amplas e complexas para toda população em geral e principalmente para os grupos específicos. O PSF trabalha com a estratégia privilegiada na qual é intensificada ações de promoção da saúde e prevenção do HIV, garantindo melhor qualidade de vida aos indivíduos portadores do HIV/AIDS e familiares (São Paulo, 2003).

"Uma boa assistência pode melhorar, em muito, a qualidade de vida das pessoas com HIV”, segundo Silva et al. (2005). As ações visam, particularmente, a fortalecer vínculos familiares e sociais na assistência e convivência com as pessoas acometidas pelo HIV/AIDS. Além disso, devem ser desenvolvidas estratégias a fim de promover o aumento da adesão ao tratamento, às normas de biossegurança e prevenção as DST/AIDS pelos usuários, familiares e cuidadores.

Para Zoboli (2003), no campo da bioética, são vários os estudos que abordam as questões de ética enfrentadas pelos profissionais de saúde que atuam em hospitais e em serviços e saúde de maior complexidade, e pouco se observam estudos que discutem os conflitos éticos vivenciados nos serviços de atenção básica, 
principalmente em unidades básicas de saúde. Para a autora, a emergência e o imediatismo das situações vivenciadas nos Prontos-Socorros e hospitais evidenciam os problemas éticos presentes nessas situações, diferentemente das situações existentes nos serviços de atenção básica, onde as ações de saúde buscam resultados a longo prazo e onde os conflitos éticos podem passar despercebidos.

As discussões sobre os conflitos éticos que os profissionais de saúde do PSF encontram no seu cotidiano sobre a manutenção das informações e da privacidade dos usuários, especialmente na questão do HIV/AIDS, são objetos do presente estudo e podem servir como subsídios para a reflexão das práticas do PSF e conseqüentemente para a melhoria da qualidade da assistência em saúde.

\section{OBJETIVO}

Discutir as situações que envolvem questões de privacidade e sigilo das informações nas experiências de assistência às mulheres portadoras de HIV/AIDS, vivenciadas pelas equipes do Programa Saúde da Família. 


\section{METODOLOGIA}

\subsection{QUADRO TEÓRICO-METODOLÓGICO Bioética, Autonomia, Privacidade e Sigilo.}

Na década de 70, o estudioso Van Rossenlaer Potter buscava uma palavra que pudesse expressar a união dos conhecimentos científicos com as questões de ética, chegando ao termo bioética (Zoboli, 2003). Para Zoboli (2006), seu intuito era “ajudar a humanidade em direção a uma participação racional, mas cautelosa, no processo da evolução biológica e cultural”, já que o termo é resultado do equilíbrio entre os valores humanos e a orientação científica da biologia.

Bioética, no sentido amplo de ética da vida, aproxima a raiz bios, que diz respeito não só à biologia, mas a todas as ciências da vida, tais como, ecologia, medicina, enfermagem, ciências sociais e outras, com ethos, que diz respeito aos valores implicados nos conflitos da vida (Pessine e Brachfontaine, 2000).

Zoboli (2003; 2006) aponta que bioética é uma nova maneira de tratar a ética nas ciências da vida e da saúde, combinando "estudo e reflexão e traçando uma ponte entre as ciências biológicas e as humanas mediante um diálogo inclusivo, plural e responsável na busca da sabedoria, entendida como a compreensão de como usar o conhecimento para o bem social e para a promoção da dignidade humana e da boa qualidade de vida”.

A partir dos anos 80, a bioética é utilizada no campo da saúde, situando a relação clínica no contexto de um sistema de saúde e incorporando a reflexão de questões relativas à estrutura, à gestão e ao financiamento. Com a difusão da bioética, tornou-se imperativo a inclusão dos problemas da coletividade na agenda das discussões, com temas relativos ao acesso aos serviços de saúde, alocação de recursos em saúde entre outras questões, (Pessini e Brachfontaine, 2000). A ética da 
saúde ocupa lugar de destaque no conjunto das reflexões éticas, justamente porque enfoca questões relacionadas à manutenção e à qualidade de vida das pessoas, fatos muito discutidos na atualidade (Zoboli, 2003).

A bioética, como já comentado antes, tem deixado de lado as questões de Saúde Pública e de Saúde Coletiva, porque tem se dedicado muito mais à reflexão e discussão dos problemas de ordem ética enfrentados pelos profissionais de saúde que atuam nos hospitais e outros serviços de saúde que concentram a incorporação de alta tecnologia. Dessa forma, os estudos acabam negligenciando a rede básica de saúde, principalmente, as unidades básicas de saúde e serviços de baixa complexidade (Zoboli, 2003).

De acordo com autores citados por Zoboli (2003) em sua tese de doutorado sobre bioética e atenção básica, estão elencados alguns fatores que indicam por que os problemas éticos enfrentados na atenção básica devem diferir dos identificados nas demais esferas de atendimento.

Em primeiro lugar observa-se que os problemas de saúde encontrados nos diversos serviços de assistência se diferenciam de acordo com o nível das ações e dos procedimentos oferecidos e prestados. Ou seja, os problemas vivenciados num serviço de saúde de maior complexidade estão relacionadas às ações imediatas em saúde, diferentemente das ações de transformação a longo prazo realizadas em serviços de atenção primária.

Em segundo lugar, os sujeitos éticos, isto é, os usuários, os familiares e os profissionais de saúde são diferentes. Os usuários de um serviço de saúde hospitalar, pela própria condição da internação, estão com sua autonomia mais comprometida do que os não hospitalizados. Os profissionais de saúde, na atenção básica, usualmente buscam objetivos de longo prazo como, por exemplo, a transformação dos perfis epidemiológicos da coletividade a partir da atenção integral e não somente o tratamento de um problema pontual.

O cenário em cada tipo de serviço de saúde difere e isto tem importância na medida em que os problemas de ordem ética emergem do contexto no qual se inserem. Nas unidades básicas de saúde, os encontros entre os profissionais de saúde e os usuários são mais freqüentes e em situações de menor urgência. Assim, a emergência, o imediatismo e a dramaticidade das situações vivenciadas, por 
exemplo, nos pronto-socorros fazem com que os problemas éticos sejam freqüentemente mais evidentes, tempestuosos e conturbados, enquanto nas unidades básicas de saúde apresentam-se de maneira mais sutil, passando, na maioria das vezes, despercebidos.

E por fim, mesmo que se observe uma estrutura similar do raciocínio ético, os sujeitos éticos e o contexto são distintos, e por isso as soluções encontradas para problemas éticos similares podem diferir nos diversos serviços de atenção à saúde.

A bioética, na vertente principialista, também conhecida como principialismo, propicia uma linguagem simples e objetiva, e que possibilita a expressão de percepções e sentimentos éticos, permitindo uma abordagem sistematizada de problemas da prática cotidiana, sendo assim mostra-se atrativa para as práticas da atenção à saúde (Pessini e Barchifontaine 1998).

Em um dos princípios da bioética, no enfoque princialista, está a Autonomia. Do ponto de vista histórico, o conceito de autonomia individual possui uma longa evolução. Segundo Selli (1998), vêm do grego, autos = eu e nomos = lei. Ou seja, a Autonomia é a capacidade especificamente humana de agir de acordo com sua vontade, diante de objetivos por ela estabelecidos.

A autonomia é a capacidade de decidir por si mesmo nas questões que dizem respeito a si próprio, como indivíduo. O princípio ético da autonomia preconiza que, quando o indivíduo tem condições de pensar decidir e agir de modo livre e independente, é dele o direito de decidir, participar e consentir sobre as decisões que dizem respeito à sua pessoa (Ferreira apud Selli, 2007).

Na bioética, a noção de ética da igualdade entre médico e usuário retornou com o conceito de autonomia e estabeleceu as bases para garantias jurídicas do usuário diante do profissional da medicina e das instituições de saúde (Selli, 1998).

Pessini e Barchifontaine (1998), ao refletirem sobre a questão da autonomia, enfatizam que a comunicação e o diálogo trazem à tona todos os tipos de influências desconhecidas acerca das escolhas a serem feitas e que isso faz parte do exercício da Autonomia.

De acordo com Bueno (1963), deriva do princípio da autonomia o direito à privacidade, que engloba a intimidade, a vida privada, a honra e a imagem da pessoa. 
A privacidade indica aquilo que é próprio de alguém e que não é público, engloba o que é pessoal e íntimo.

A privacidade parte do princípio que a pessoa é autônoma para decidir a quem e como deseja permitir que seu corpo seja exposto para procedimentos médicos, diagnósticos e assistenciais ou quais informações a respeito de suas condições de saúde devem ser confidencializadas (Massarollo, Sacardo e Zoboli, 2006). Do indivíduo autônomo deriva a liberdade de guardar para si mesmo fatos pessoais que não deseja revelar aos outros. A privacidade, para efeitos didáticos, é dividida em três dimensões: privacidade física, privacidade de informações e privacidade decisional ou de decisão (Sacardo apud Allen , 2001).

A privacidade física é o uso mais popular do termo e indica que a pessoa autônoma é quem decide com quem deseja estabelecer um contato. A autora diz que as demandas no cuidado com a saúde na modernidade pressupõem um contato muitas vezes íntimo, como a nudez, o toque e a observação entre os profissionais, especialmente os médicos e os usuários para a realização de exames, tratamentos, cirurgia e hospitalização.

O segundo uso do conceito de privacidade, privacidade das informações, requer limites de acesso às informações pessoais. Isto inclui informações extremamente modernas, como por exemplo, o código dos materiais genéticos de uma pessoa. Para a autora, a preservação da privacidade das informações é fundamental por afetar a qualidade da assistência à saúde. Este conceito, segundo a autora, é "sinônimo de segredo, confidência ou anonimato".

O terceiro uso do conceito, a privacidade decisional ou de decisão, mostra as escolhas que o usuário faz livre de interferências de outras pessoas, seja de médicos, profissionais da saúde, familiares ou amigos sobre seu tratamento, levando em consideração suas expectativas, crenças e valores.

O presente estudo tratará da abertura da privacidade e da revelação sobre o diagnóstico do HIV/AIDS. Entende-se que a garantia da privacidade requer a observação da confidencialidade das informações por parte dos profissionais de saúde e outros profissionais que por ventura venham a ter acesso a tais informações. 


\subsection{Cenário de estudo}

O presente estudo foi desenvolvido no Município de São Paulo, na Supervisão de Área de Saúde da Freguesia do Ó e Brasilândia, pertencentes à Coordenadoria de Saúde da Regional Norte. Abrange os distritos administrativos de Freguesia do Ó e Brasilândia, nos quais vivem 392000 habitantes distribuídos em uma área de 31,5 km² (IBGE, 2000).

No início dos anos 80, a região de Freguesia do Ó e Brasilândia foi contemplada com o modelo assistencial conduzido por um Sistema de Saúde regionalizado e hierarquizado, tendo a UBS como porta-de-entrada do Sistema. Na ocasião, a região dispunha apenas do Hospital Maternidade Escola Vila Nova Cachoeirinha como equipamento de saúde de nível terciário, e as poucas UBS funcionavam precariamente em casas alugadas.

Iniciou-se então o planejamento para a construção do Módulo de Saúde com participação efetiva da comunidade. Nesse projeto foram construídos mais três hospitais gerais, 15 UBS e foi feita a reforma de cinco UBS existentes. Era um momento no quais os movimentos de saúde da região da Brasilândia, representada por 22 vilas e bairros, vinham lutando por melhorias nas condições de vida e de saúde, reivindicando rede de esgoto, água e asfalto para a região, além de participar efetivamente da procura de terrenos para a construção de hospitais e UBS.

Sob a responsabilidade da Coordenadoria de Saúde de Freguesia do Ó/Brasilândia, encontravam-se até dezembro de 2006, um Ambulatório de Especialidade da Freguesia do Ó, um Centro de Atenção Psicossocial (CAPs), um Pronto-Socorro Municipal, um Centro de Referência DST/Aids, 16 Unidades Básicas de Saúde, destas, nove com PSF, sendo três em parceria com a Fundação Zerbini , a UBS Dr. Augusto Leopoldo Ayrosa Galvão, a UBS Vila Penteado e a UBS Vila Ramos.

\footnotetext{
* Parceiro de co-responsabilidade até 31de março de 2007.
} 
O panorama epidemiológico do HIV/AIDS na Coordenadoria de Saúde da Freguesia do Ó/Brasilândia mostra um total de 2.401 casos de aids de 1980 a julho de 2004, sendo destes, 1.377 casos pertencentes ao distrito administrativo Brasilândia e 1.024 casos de aids no distrito da Freguesia do Ó (São Paulo, 2004). A trajetória da aids se mostra semelhante entre os dois distritos administrativos, com aumento no número de casos a cada ano até 2000 e redução a partir de então, até 2005 (São Paulo, 2005).

No distrito administrativo da Freguesia do Ò o quadro epidemiológico referente à aids também tem maior incidência em 1996 (86,2 por 100 mil habitantes) e queda desse número até o ano de 2002 (63,7 por 100 mil habitantes). Os dados mostram que no ano de 2003 houve um aumento nas taxas de incidência da aids (67,0 por 100 mil habitantes) comparado ao ano de 2002 (São Paulo, 2004).

O quadro epidemiológico do distrito Brasilândia, onde está localizada a UBS Vila Penteado, mostra que o número de casos de aids aumentou gradativamente no período de 1980 a 2000. Na primeira década deste período, de 1980 a 1990, foram 144 casos notificados, e nos últimos anos deste período, de 1996 a 2000, observamse 579 casos de aids. Após este período há uma queda do número de casos notificados até o ano de 2003, verificando-se um total de 268 casos de aids entre os anos de 2001 até 2003 (São Paulo, 2004).

Ao analisar os casos de aids segundo a categoria de exposição hierarquizada no período de 1980 a 2004, observa-se que a transmissão do vírus por via sexual de práticas heterossexuais ocupa primeiro lugar no cenário Freguesia do Ó/Brasilândia. Em segundo lugar está a transmissão do HIV via uso de drogas injetáveis, em terceiro a via sexual de transmissão por práticas homossexuais e, por último, ocupa a quarta posição a transmissão do HIV por via sexual por práticas bissexuais (São Paulo, 2004).

O presente estudo foi desenvolvido na Unidade Básica de Saúde Vila Penteado, localizada no distrito administrativo de Brasilândia. Na região de Vila Penteado foram selecionados dois terrenos para a construção da UBS, e foi escolhido o terreno do Parque Pedroso, pois contemplava a comunidade da região*.

Informações retiradas do Relatório da Unidade do curso de Especialização em Gerência de Unidade Básica de Saúde do SUS/ SMS - SP, de autoria de Yoshimi Ito Villanova (Qualis P. S. F. V. Penteado), São Paulo, dez 2002. 
Assim, em janeiro de 1990, a UBS Vila Penteado, que antes funcionava precariamente em uma casa alugada na Rua dos Navegantes, mudou-se para um prédio próprio na Rua Urepava. A instalação física da UBS Vila Penteado foi construída em três pavimentos por conta da topografia da região. Na área térrea é feito o atendimento, no subsolo um há a saúde bucal e a administração, e no subsolo dois existe o estacionamento. Há acesso para deficientes físicos como rampas e sanitários.

A unidade opera com o modelo assistencial do PSF desde abril de 1998, inicialmente no projeto Qualidade Integral á Saúde/ Programa Saúde da Família (Qualis/PSF) através da parceria Secretaria Estadual da Saúde de São Paulo e Secretaria Municipal da Saúde e Fundação Zerbini.

Possui horário de funcionamento das 7h às 19 h. A UBS Vila Penteado não é o local onde a pesquisadora exerce suas atividades profissionais e foi escolhida por ter uma história de luta popular e por ser a UBS aquela com maior número de equipes de PSF da região.

Como referência secundária, a UBS Vila Penteado conta com o Ambulatório de Especialidades Edgar Montoanelli, onde também funciona o Centro de Referência de DST/AIDS e o Hospital Geral Vila Penteado.

Após a contratação das equipes de PSF, iniciou-se o cadastramento das famílias em áreas delimitadas. Em 2002 havia 6.108 famílias cadastradas, sendo 23 391 pessoas, atendidas por apenas quatro equipes. No segundo semestre do ano de 2005, houve a entrada de mais três equipes de PSF, o que possibilitou a readequação da área e a redistribuição das famílias. Atualmente, de acordo com o Sistema de Informação da Atenção Básica, com dados de março de 2007, existem 24665 pessoas e 6857 famílias cadastradas.

O atendimento é feito através da territorialização, ou seja, cada equipe atende a população residente no território de sua responsabilidade, e todos os territórios das equipes conformam à área de abrangência da UBS. As equipes atendem através do acolhimento que é a demanda espontânea que bate à porta da UBS com queixas pontuais, atendem pelo agendamento de consultas médicas e de enfermeiras, nos Grupos educativos e de consultas, e nas visitas domiciliares. Os auxiliares de enfermagem, além de participarem das atividades das equipes, também compõem a 
escala de cobertura de ambulatório que abrange atividades como a coleta de exames, curativo e vacinação.

\subsection{Sujeitos da Pesquisa}

Os sujeitos de pesquisa foram os profissionais de saúde que compõem as sete equipes de PSF da UBS Vila Penteado: médicos, enfermeiras, auxiliares de enfermagem (AE) e agentes comunitários de saúde (ACS). Dos sete médicos, cinco foram entrevistados, dois não dispunham de horário para a entrevista, mesmo após várias tentativas.

Do total de sete enfermeiras, seis foram entrevistadas e uma enfermeira estava de licença maternidade. Todas as 14 auxiliares de enfermagem foram entrevistadas.

\subsection{Coleta de Dados}

Os dados foram coletados através de uma entrevista individual realizada com médicos, enfermeiras e auxiliares de enfermagem. Junto aos ACS, foi utilizada a metodologia do Grupo Focal. Entre os profissionais técnicos, não foi possível realizar a coleta de dados através da metodologia de grupo focal, pois poderia prejudicar o processo de trabalho da UBS e das equipes ao reunir todos os profissionais de uma mesma categoria. 
Uma vez escolhidas as datas para a coleta dos dados, a proposta do estudo e o termo de consentimento livre-esclarecido foram apresentados aos sujeitos de pesquisa (Anexo 01). Os Grupos Focais e as entrevistas foram realizadas na UBS e seguiram um roteiro semi-estruturado (Anexo 02 e Anexo 03 respectivamente). As entrevistas e os Grupos foram gravados em fitas cassete.

O Grupo Focal é um método oral e uma técnica qualitativa, não diretiva, na qual os entrevistados não buscam o consenso, mas trazem à tona opiniões e discussões pertinentes de determinadas problemáticas. Essa técnica possibilita uma visão ampla a respeito das percepções e comportamentos de um grupo de pessoas, revelando as variações que existem em termos de experiências. Para Minayo (2004), o grupo focal consiste numa técnica importante para focalizar as questões da saúde sob o ângulo do social, porque se presta ao estudo de relações de profissionais da área e a população. O agente comunitário é um profissional e, ao mesmo tempo, também é um membro da comunidade e pode trazer contribuições importantes para o alcance dos objetivos do estudo.

O grupo é coordenado por um moderador, ou facilitador, que conduz o grupo por meio de perguntas pré-definidas, ajudando os participantes a entrarem na discussão o mais naturalmente possível. A presença de um animador que introduz a discussão e a mantém acessa dentro do tempo previsto, encoraja a palavra de cada um, enfatiza que não há respostas certas ou erradas e observa a comunicação nãoverbal. Também coloca que o grupo deve durar entre uma e uma hora e meia, dependendo da dinâmica das discussões (Minayo apud Schrimshaw, 2004).

Os grupos focais foram realizados na própria UBS num horário agendado com a Direção do serviço. É importante ressaltar a garantia do sigilo das informações, esclarecendo que os dados não serão divulgados de forma a possibilitar a identificação dos participantes, pois os dados serão divulgados de forma agregada.

Iniciou-se a coleta de dados com o conhecimento da UBS e de sua gerência. Com horário marcado por telefone, fui recebida pela gerente que também contou sobre a história da UBS e da comunidade adstrita à unidade. Neste dia foi agendada a data para a realização dos Grupos Focais com os agentes comunitários.

Os grupos focais foram realizados no período da tarde de uma sexta-feira; o primeiro grupo teve início às $13 \mathrm{~h}$ e término às 15 horas, contando com a participação 
de 18 agentes comunitários. O segundo grupo, ocorrido das 15 h30 às 17 h30, contou com a presença de 20 agentes. As entrevistas duraram em média 45 minutos, sendo a que a de menor tempo abrangeu um total de 30 minutos e a de maior duração de uma hora e 30 minutos.

Após a realização dos Grupos Focais, foi iniciada a coleta de dados através das entrevistas individuais. As entrevistas foram agendadas com cada profissional de acordo com sua disponibilidade, dentro do horário de trabalho, em locais privativos.

Esta fase de coleta teve duração de três meses, de setembro a novembro de 2006.

\subsection{Instrumentos de coleta de dados}

Foram elaborados dois instrumentos de coleta de dados. O instrumento utilizado para os Grupos Focais nos quais participam os agentes comunitários, é composto pela caracterização dos ACS e por dez questões norteadoras e abertas, que buscam observar aspectos sobre o sigilo do diagnóstico do HIV entre usuária, família, ACS e equipe de PSF, além de aspectos sobre a assistência a essas usuárias (Anexo 02).

Para a realização das entrevistas individuais com médicos, enfermeiras e auxiliares de enfermagem foi utilizado um instrumento composto por quatro partes, com questões abertas (Anexo 03).

A primeira parte descreve o profissional entrevistado quanto à sua formação acadêmica, quantidade de anos trabalhados na área da saúde, no PSF e na UBS Vila Penteado. A segunda parte refere-se às questões abertas sobre os casos de mulheres com HIV com as quais o profissional se relaciona, abrangendo o sigilo do diagnóstico, a assistência e o trabalho em equipe. A terceira parte da entrevista questiona o profissional quanto a suas opiniões frente à epidemia da aids, e a quarta 
parte refere-se à caracterização do profissional a fim de conhecer o corpo técnico que participa da pesquisa.

\subsection{Análise dos dados}

Trata-se de um estudo qualitativo de natureza exploratória.

Os conteúdos das entrevistas individuais e dos Grupos Focais foram organizados pela Análise de Conteúdo de Bardin (1995) e definidos como um conjunto de técnicas de análise das comunicações que permitem descrever, através de procedimentos sistemáticos, os conteúdos das mensagens, que podem ser quantitativas ou não, e a inferência dos conhecimentos relativos à produção destas mensagens, as variáveis inferidas.

Dentre as técnicas desse procedimento metodológico, utilizou-se a análise temática que "consiste em descobrir os núcleos de sentido que compõem uma comunicação e cuja presença ou freqüência signifiquem alguma coisa para o objetivo analítico escolhido".

O método de análise de conteúdo é composto por três fases: a pré-análise, a exploração do material, o tratamento dos resultados e a interpretação (Minayo, 2004).

A primeira fase, pré-análise, consiste na reunião dos materiais e documentos a serem analisados, na retomada das hipóteses e dos objetivos iniciais da pesquisa, reformulando-se frente ao material coletado. É decomposta na seguinte tarefa da Leitura flutuante, que consiste em tomar contato exaustivo com o material, deixandose “impregnar" pelo seu conteúdo. O pesquisador apropria-se da leitura frente às hipóteses iniciais e pré-existentes, e deve orientar-se pelos objetivos iniciais da pesquisa. A pré-análise é a fase de organização do material em que se especifica o campo no qual o pesquisador deve fixar sua atenção 
Na segunda fase, exploração de materiais, procede-se a codificação, que é a transformação de dados brutos visando a alcançar a compreensão do núcleo de compreensão do texto.

A terceira fase, concomitante à segunda, é a de tratamento dos dados no qual o conteúdo será agrupado de acordo com temáticas já colocadas no estudo. Na fase da descrição analítica, o material empírico recebe tratamento, incluindo a codificação, a classificação e a categorização. O tema, como unidade de registro, corresponde a uma regra de recorte do sentido e não da forma da comunicação. Por unidade de registro, entende-se a unidade de significação a codificar, ou seja, o segmento de conteúdo a ser considerado como unidade de base a ser categorizada. A noção de tema em análise de conteúdo é uma afirmação sobre um assunto, que pode ser vista em uma frase que servirá de guia para a leitura (Bardin, 1995).

E a quarta fase, de interpretação dos dados, compreende o momento no qual haverá convergência e divergência de idéias sobre os dados obtidos e o quadro teórico apresentado. Os resultados obtidos são colocados de forma organizada e que serão discutidos com aporte teórico já trabalhado no estudo. Optou-se, no presente estudo, por se observar esse procedimento para agrupar os problemas identificados, pois a categorização simplifica os dados coletados e facilita sua interpretação.

Dessa maneira, após as entrevistas individuais e os Grupos Focais, os conteúdos dos depoimentos dos profissionais de saúde, resultaram na obtenção de textos, que após decomposição conformaram um conjunto de temas:

\subsection{ASPECTOS ÉTICOS}

O projeto foi aprovado pelo Comitê de Ética da Secretaria Municipal de Saúde de São Paulo e pelo Comitê de Ética da Fundação Zerbini.

Ao iniciar a coleta de dados, foram explicados os objetivos da pesquisa, e solicitada assinatura do termo de Consentimento Livre e Esclarecido, assinado em 
duas vias, uma para o pesquisador e outra para o entrevistado (Anexo 01). As entrevistas foram gravadas em fitas cassete com permissão dos entrevistados.

De acordo com a resolução CNS/MS 196/96 que regulamenta a ética em pesquisa envolvendo seres humanos no Brasil, foi pedido a cada um dos profissionais de saúde que irão participar o seu consentimento livre e esclarecido para a participação da pesquisa. Este consentimento foi registrado em um termo escrito e tomado oralmente, ou seja, o próprio depoimento gravado é tido como a concordância do profissional em participar. Este procedimento visa a garantir o anonimato dos participantes e assegurar que se sintam protegidos e seguros para abordar as questões relativas às ações de saúde prestadas. 


\section{RESULTADOS E DISCUSSÃO}

\subsection{CARACTERIZAÇÃO DOS SUJEITOS DE PESQUISA}

Foram realizados dois grupos focais, o primeiro com 18 ACS e o segundo com 10, entrevistas individuais com seis enfermeiras, cinco médicos e 14 auxiliares de enfermagem.

Segue abaixo o Quadro 1 sobre a caracterização dos entrevistados, médicos, enfermeiras e auxiliares de enfermagem, quanto ao sexo, idade, formação profissional e tempo de experiência na área da saúde, no PSF e na UBS pesquisada.

Quadro 1: Caracterização dos profissionais quanto ao sexo, idade, formação profissional, tempo de experiência na área da saúde, no PSF e na UBS Vila Penteado.

\begin{tabular}{|c|c|c|c|c|c|c|c|}
\hline \multirow{2}{*}{\multicolumn{2}{|c|}{$\begin{array}{l}\text { Categorias } \\
\text { Profissionais } \\
\qquad / n^{\circ}\end{array}$}} & \multirow{3}{*}{$\begin{array}{c}\text { Sexo } \\
\\
\mathrm{F} \\
\end{array}$} & \multirow{3}{*}{$\begin{array}{c}\text { Idade } \\
\text { (anos) } \\
45 \\
\end{array}$} & \multirow{3}{*}{$\begin{array}{l}\text { Formação Profissional } \\
\text { Especialização em PSF }\end{array}$} & \multicolumn{3}{|c|}{ Tempo de trabalho (anos) } \\
\hline & & & & & \multirow{2}{*}{$\begin{array}{c}\text { Saúde } \\
19 \\
\end{array}$} & \multirow{2}{*}{$\begin{array}{c}\text { PSF } \\
8 \\
\end{array}$} & \multirow{2}{*}{$\begin{array}{c}\begin{array}{c}\text { UBS } \\
\text { V. Penteado }\end{array} \\
19\end{array}$} \\
\hline \multirow{7}{*}{ 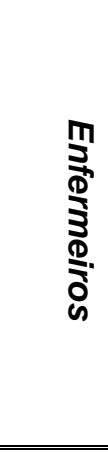 } & 01 & & & & & & \\
\hline & 02 & $\bar{F}$ & 56 & $\begin{array}{l}\text { Especialização em PSF e } \\
\text { Gerenciamento de } \\
\text { Enfermagem }\end{array}$ & 20 & 8 & 8 \\
\hline & 03 & $\mathrm{~F}$ & 35 & Especialização em PSF & 8 & 8 & 8 \\
\hline & 04 & $\overline{\mathrm{F}}$ & 28 & Residência em PSF & 5 & 4 & 1 \\
\hline & 05 & $\bar{F}$ & 30 & $\begin{array}{c}\text { Especializações em PSF } \\
\text { e nefrologia }\end{array}$ & 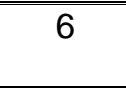 & 4 & 4 \\
\hline & 06 & $\mathrm{~F}$ & 26 & Especialização em PSF & 4 & 4 & 1 \\
\hline & 07 & & & licença maternidade & & & \\
\hline \multirow{5}{*}{ 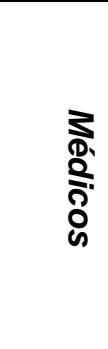 } & 01 & $\mathrm{M}$ & 48 & $\begin{array}{l}\text { Especializações em PSF, } \\
\text { ginecologia e obstetrícia }\end{array}$ & 22 & 7 & 7 \\
\hline & 02 & $\mathrm{~F}$ & 43 & $\begin{array}{c}\text { Especializações em PSF } \\
\text { e homeopatia }\end{array}$ & 17 & 6 & 6 \\
\hline & 03 & $\mathrm{M}$ & 27 & Sem especialização & 1 & 1 & 1 \\
\hline & 04 & M & 31 & $\begin{array}{l}\text { Especialização em } \\
\text { medicina do trabalho }\end{array}$ & 7 & 7 & 1 \\
\hline & 05 & $\mathrm{M}$ & 29 & Especialização em PSF & 5 & 4 & 2 \\
\hline
\end{tabular}




\begin{tabular}{|c|c|c|c|c|c|c|c|}
\hline & 06 & recusa & & & & & \\
\hline & 07 & recusa & & & & & \\
\hline \multirow{14}{*}{ 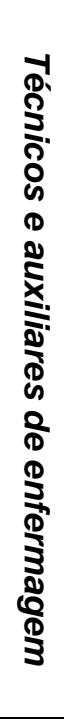 } & 01 & $\mathrm{~F}$ & 38 & Auxiliar de enfermagem & 8 & 8 & $\begin{array}{c}8 \text { (4 como } \\
\text { ACS) }\end{array}$ \\
\hline & 02 & $\mathrm{~F}$ & 36 & Técnico de enfermagem & 8 & 6 & 4 \\
\hline & 03 & $\mathrm{~F}$ & 41 & Auxiliar de enfermagem & 8 & 2 & 2 \\
\hline & 04 & $\mathrm{~F}$ & 53 & Auxiliar de enfermagem & 16 & 8 & 1 \\
\hline & 05 & $\mathrm{~F}$ & 28 & Auxiliar de enfermagem & 8 & 8 & 8 \\
\hline & 06 & $\mathrm{~F}$ & 41 & Técnico de enfermagem & 9 & 8 & 1 \\
\hline & 07 & $\mathrm{~F}$ & 46 & Técnico de enfermagem & 11 & 8 & 8 \\
\hline & 08 & $\mathrm{~F}$ & 52 & Técnico de enfermagem & 26 & 9 & 9 \\
\hline & 09 & $\bar{F}$ & 39 & Auxiliar de enfermagem & 5 & 5 & 1 \\
\hline & 10 & $\mathrm{~F}$ & 40 & Auxiliar de enfermagem & 17 & 8 & 17 \\
\hline & 11 & $\bar{F}$ & 50 & Técnico de enfermagem & 24 & 6 & 6 \\
\hline & 12 & $\mathrm{~F}$ & 38 & Técnico de enfermagem & 15 & 8 & 8 \\
\hline & 13 & $\mathrm{~F}$ & 40 & Técnico de enfermagem & 18 & 10 & 10 \\
\hline & 14 & $\mathrm{~F}$ & 28 & Técnico de enfermagem & 8 & 1 & $<1$ \\
\hline
\end{tabular}

Em relação às seis enfermeiras, todas eram do sexo feminino, com uma média de idade de 35,8 anos. Todas tinham formação profissional de Pós-Graduação, seja em residência ou em especialização em PSF; duas tinham também formações em Nefrologia e Gerenciamento de Enfermagem. Com relação ao tempo de trabalho na área da saúde, observou-se que é um grupo relativamente jovem, a maioria, quatro, com menos de oito anos de trabalho na área da saúde. Das seis enfermeiras entrevistadas, todas participaram de alguma capacitação na temática da aids.

Metade delas tinha tempo de experiência de trabalho na área da saúde coincidente com o tempo de PSF e de unidade de saúde. Ou seja, iniciaram na UBS Vila Penteado, quando esta passou a operar o PSF. Duas enfermeiras, embora estivessem há menos de dois anos na unidade, já possuíam experiência no PSF há pelo menos quatro anos. Dado que todas têm residência ou especialização em PSF e experiência acumulada no PSF, pode-se afirmar que as enfermeiras, na maioria, conhecem a dinâmica de trabalho da UBS e de suas equipes, as famílias e o seu território. Todas as seis enfermeiras participaram de alguma capacitação na temática aids.

Entre os médicos entrevistados, quatro era do sexo masculino e um era do sexo feminino. A média de idade encontrada foi 29,8 anos. Dois não tinham 
especialização em PSF. Os outros três, além da especialização em PSF, possuíam formação em ginecologista, obstetrícia e homeopatia.

Em relação à experiência na área da saúde, dois médicos possuíam mais de 17 anos e os outros três menos de sete. A maioria deles, três, teve experiência de trabalho no PSF adquirida na UBS Vila Penteado. Dois deles ingressaram nesta unidade há menos de dois anos. Dos cinco médicos entrevistados, quatro disseram ter participado de alguma capacitação na temática da aids.

Em relação ao cargo de auxiliar de enfermagem, do total de 14, seis tinham formação de auxiliar e oito de técnico de enfermagem. A maioria dos auxiliares de enfermagem tem curso técnico, ou seja, as equipes comportam pessoas com escolaridade maior do que é exigido para o cargo.

Todos os profissionais eram do sexo feminino, com idade média de 40,7 anos. Quase a totalidade dos 14 auxiliares, doze, tinha mais do que cinco anos de experiência de trabalho no PSF, e nove das auxiliares tinham quatro ou mais anos de trabalho na UBS Vila Penteado. Dentre as 14 auxiliares entrevistadas, oito disseram ter participado de alguma capacitação na temática da aids.

Considera-se que a maioria dos auxiliares tem boa experiência em PSF, dado o tempo de atuação no programa e na UBS, inferindo-se que de um modo geral o grupo de auxiliares de enfermagem conhece bem a dinâmica do trabalho do programa, as famílias e o território.

Do total de 38 ACS da UBS Vila Penteado, 28 participaram dos grupos focais, sendo a maioria do sexo feminino (25). A média de idade foi de 38,9 anos, o mais jovem tinha 23 anos e o mais velho, 52. Do total dos ACS, 15 trabalhavam na UBS há menos de dois anos e 13 entre quatro e nove anos. Vinte e três ACS participaram de capacitação na temática aids.

A caracterização mostra que a média de idade dos auxiliares de enfermagem e ACS é maior do que a encontrada entre as enfermeiras e médicos. O médico é o profissional mais jovem em termos de média de idade. A auxiliar de enfermagem é aquela que possui o maior tempo de experiência em PSF, muitas delas estavam no programa desde o seu início. Inclusive uma delas atuou durante quatro anos como ACS antes de assumir o cargo de auxiliar de enfermagem. São as auxiliares de 
enfermagem que possuem maior tempo de trabalho na UBS Vila Penteado quando comparado aos demais.

\subsection{A REVELAÇÃo DO DIAGNÓSTICO DE HIV PARA A USUÁRIA}

A revelação pelas equipes de PSF do diagnóstico de HIV para a usuária foi analisada segundo as situações que fizeram com que o(s) membro(s) da equipe suspeitasse(m) da infecção e indicasse(m) a realização do teste sorológico, e como se deu o momento de revelação.

De acordo com as falas dos ACS, médicos, enfermeiras e auxiliares de enfermagem, foram classificadas três situações em que o profissional de saúde do PSF solicitou o teste anti-HIV às usuárias.

Na primeira situação, a solicitação do teste foi feita pelo profissional médico e/ou enfermeira na consulta, quando havia suspeita de infecção pelo HIV, aventada pela presença de sintomatologia da infecção, pela história de vida da usuária ou alguma indicação de comportamento de risco.

Ao realizar a anamnese, se o profissional de saúde, de um modo geral, percebe indícios de que um usuário encontra-se em situações de risco de infecção pelo HIV, passa a solicitar o teste diagnóstico. (Ferraz, 1998)

Para os profissionais de saúde do PSF, como têm estreita proximidade das famílias, do modo de vida de seus membros, de suas relações no território, tem mais elementos para identificar situações que podem indicar uma possível infecção pelo HIV.

Neves (2003) relata que do ponto de vista epidemiológico não se justifica a realização do teste sorológico anti-HIV indiscriminadamente para toda a população. Porém, de acordo com a magnitude da infecção do HIV/AIDS, a oferta para a realização do teste anti-HIV deve ser feita para aquelas pessoas com história de exposição a uma possível situação que possa indicar risco para a infecção. Por exemplo, para pessoas com história de doenças ou agravos que comumente estão 
associados à infecção pelo HIV, tais como tuberculose, doenças sexualmente transmissíveis, recomenda-se a oferta de realização do teste anti-HIV.

Destaca-se que, no presente estudo, que chamou a atenção dos profissionais, além dos sintomas, os chamados “comportamentos de risco”, quais sejam, história de uso abusivo de álcool, a falta de adesão ao tratamento de outros agravos, como a hipertensão arterial, a falta de proteção na relação sexual, conforme pode-se contatar nas falas a seguir:

“(...) fui vendo pelos sintomas, a falta de uso do preservativo, aí pedi a sorologia. Ela é muito rebelde, bebe em excesso e é hipertensa (...) não cuida da hipertensão, não vem nos grupos (...)”- médico.

"Eu tenho um caso de uma paciente que veio fazer os exames de rotina e pela história da paciente, o médico solicitou o exame... Ela é alcoólatra e tem uma história difícil (...)” - ACS.

“Ela era alcoólatra, uma mulher que bebe muito, cai na rua e nem sabe onde está (...) em uma das consultas o médico perguntou se ela gostaria de fazer o teste e ela disse que sim. Foi quando o resultado veio positivo." - enfermeira.

A segunda situação de solicitação do teste anti-HIV ocorreu quando um outro membro da equipe trouxe a preocupação ao médico e/ou enfermeira em relação a um possível diagnóstico. O ACS foi um dos profissionais que mais trouxeram a preocupação.

A conformação da equipe do PSF incorpora um novo trabalhador ACS. Este possui uma situação singular, uma vez que deve obrigatoriamente residir na área de atuação da equipe e exercer a função de elo entre a equipe e a comunidade, o que pode fazer com que viva o cotidiano da comunidade com maior intensidade do que os outros membros da equipe de saúde. Por ter maior proximidade com o usuário, por habitar o mesmo bairro, e ainda, por adentrar freqüentemente o domicílio das famílias, o ACS é um integrante da equipe de saúde da família que traz contribuição 
fundamental nas relações com os usuários do sistema público de saúde (Fortes e Spinetti, 2004).

Os ACS têm um papel fundamental na questão do HIV/AIDS no sentido de reconhecer mais precocemente, nas famílias, possíveis portadores e encaminhar para os cuidados necessários.

“... eu sabia que o parceiro da paciente era soropositivo e que a ela não sabia disso. Aí eu discuti o caso apenas com a médica da equipe que decidiu conversar com o parceiro em consulta médica. Depois o casal voltou junto à consulta." - ACS.

Os ACS acabaram sabendo de casos existentes nas famílias por meio de vizinhos e estes acabaram levando a informação para os profissionais.

"O ACS disse que todos os vizinhos falam que ela tem aids. $\mathrm{Na}$ consulta eu propus para a paciente solicitar o teste anti-HIV, mas não foi preciso porque ela me contou que era soropositiva." - médico.

A terceira situação em que o pedido de teste anti-HIV foi feito se deu no acompanhamento do pré-natal.

“(...) eu pedi o exame no pré-natal e veio um falso-positivo (...) dei a notícia para a mulher, repeti o exame e veio negativo (...)” - médico.

As diretrizes da Coordenação Nacional de DST/AIDS e do Programa de Assistência Integral à Saúde da Mulher preconizam a prática do aconselhamento e a oferta da sorologia anti-HIV de maneira integrada a um conjunto de atividades destinadas à promoção da saúde da mulher, incluídas a assistência ao pré-natal e puerpério, atendimento de queixas ginecológicas e orientações concernentes à contracepção, à prevenção e ao controle das DST e do câncer ginecológico (Neves, 2003). 
A oferta do teste na gestação é uma das principais ações do Programa de Controle das DST/AIDS. Em 1999, no Estado de São Paulo, tornou-se obrigatório o oferecimento do teste anti-HIV a todas as mulheres grávidas nos serviços de prénatal. A magnitude da infecção do HIV/AIDS e o fenômeno de feminilização da epidemia mostram a importância da solicitação do teste anti-HIV a todas as gestantes.

É bom lembrar que, segundo o Manual DST, HIV e AIDS (Brasil, 1999), a oferta do teste é obrigatória, mas a realização do exame é de caráter estritamente voluntário. Ou seja, o profissional de saúde tem como obrigação garantir o acesso da gestante ou de qualquer outro usuário à realização do teste anti-HIV, e cabe ao profissional exercer a prática do aconselhamento e expressar a importância desse teste. Porém é a gestante e o usuário que são responsáveis em fazer o teste anti-HIV voluntariamente.

O protocolo de oferecimento da sorologia anti-HIV no pré-natal estabelece que a oferta deste exame seja realizada preferencialmente pós-aconselhamento. (Neves, 2003).

O aconselhamento, segundo o Manual de Aconselhamento em DST, HIV e AIDS (Brasil, 1999), é um processo de escuta, um diálogo feito numa relação de confiança no qual o profissional de saúde centra suas atenções na fala do usuário, e que faz com que o usuário se reconheça como sujeito de sua própria saúde.

No entanto, observa-se que na prática o pedido de teste anti-HIV vem sendo realizado de forma rotineira, no conjunto dos pedidos de exames laboratoriais do prénatal, sem a realização do aconselhamento. Desta forma, perde-se a oportunidade de discutir o significado do resultado, seja ele positivo ou negativo para o HIV com a usuária.

A solicitação do teste anti-HIV implica no preparo do profissional de saúde para revelar o resultado para a usuária, particularmente quando o resultado é positivo, como foi lembrado por uma enfermeira.

"Na verdade quando a gente pede um exame de HIV tem que estar preparada para receber um resultado positivo ou negativo. Quando vem um 
negativo, tudo bem. Mas quando vem um positivo, a gente fica muito chocada (...)" - enfermeira.

No presente estudo não foi encontrado nenhum relato sobre situação em que a usuária tenha procurado a equipe para a realização voluntária do teste anti-HIV. Isto pode ter ocorrido pela não lembrança por parte dos entrevistados e ACS ou pelo fato de não ter ocorrido situação descrita.

Longa (1999) lembra que os motivos mais freqüentes para o comportamento daqueles que não buscam espontaneamente os serviços de saúde para a realização da sorologia para o HIV podem estar relacionados ao medo do diagnóstico ou de sua confirmação, à falta de informações sobre a infecção pelo HIV/AIDS e ao desconhecimento da importância de um diagnóstico precoce.

Segundo Czeresnia (1997), uma possível discriminação e rejeição social que a usuária poderá sofrer podem fazer com que esta tenha vergonha caso o seu diagnóstico seja positivo.

A falta de procura espontânea pelo teste anti-HIV pode ser justificada pela ainda sedimentada idéia de grupos de risco, lançada nas décadas de 80 e 90, que está presente no imaginário social coletivo. Por isso as pessoas ainda podem achar que não são alvos da infecção do vírus do HIV. Mas tal pensamento não se explica ao se analisar os dados epidemiológicos referentes à epidemia da aids e ao fenômeno de feminilização da epidemia.

O PSF é de extrema importância para garantir um diagnóstico precoce do HIV. O profissional do PSF, ao dialogar com as usuárias e suas famílias sobre as diferentes situações de vulnerabilidade às DST e HIV/AIDS, pode encorajar a procura espontânea pelo teste.

A partir do conhecimento sobre a soropositividade pelo profissional, passa-se ao momento de revelação do diagnóstico para a usuária.

Segue abaixo o Fluxograma 1, que representa o fluxo da informação do diagnóstico do HIV para as mulheres. 
Fluxograma 1: Fluxo da informação sobre o diagnóstico do HIV para mulheres.

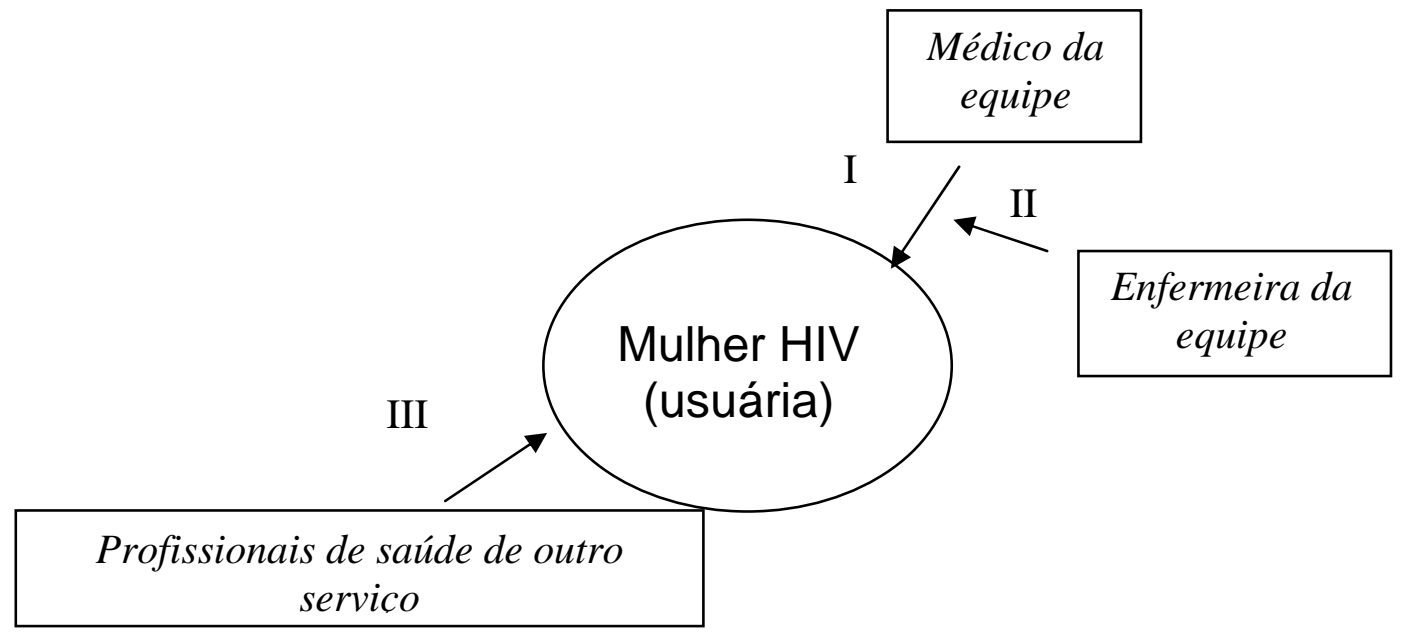

I- $\quad$ O médico revela o diagnóstico do HIV à usuária.

II- $\quad$ A enfermeira e o médico juntos revelam o diagnóstico do HIV à usuária.

III- $\quad$ Profissionais de outro serviço de saúde revelam o diagnóstico do HIV à

No fluxograma observa-se que a informação sobre o diagnóstico de HIV chegou à mulher através de três sujeitos. Representados como I e II identificou-se dois profissionais, médico e/ou enfermeira da própria UBS; como III houveram outros profissionais de outros serviços de saúde.

A revelação do diagnóstico à usuária é um momento delicado e importante, pois traz angústia, tristeza e medo, tanto para a usuária quanto para o profissional.

Numa das situações identificadas pelo ACS, após a usuária faltar várias vezes à UBS para receber o resultado do exame de diagnóstico positivo de HIV, o médico interrompeu suas consultas agendadas do dia e fez uma visita domiciliária à usuária. Entende-se tal atitude como uma preocupação fundamental do profissional, após vivenciar um momento de "impacto de diagnóstico do HIV", de estimular a responsabilidade da mulher em fortalecer seu auto-cuidado. Houve a preocupação de iniciar o quanto antes o tratamento e as ações que promovem saúde. 
“... um dia eu cheguei no posto e disse ao médico que ela (usuária) não viria pegar o resultado. O médico pediu licença aos outros pacientes e nós fomos a casa dela para entregar o resultado. Eu fiquei do lado de fora, ela atendeu o médico no quintal e ele deu o resultado... o que eles acertaram ninguém sabe." - ACS.

Outra situação de revelação do diagnóstico ocorreu num trabalho em parceria do médico e da enfermeira da equipe.

“Oito anos atrás chegou um resultado de HIV positivo de uma mulher. Eu e o médico ficamos quebrando a cabeça de como revelar esse diagnóstico à paciente. Decidimos que o resultado seria dado por nós dois juntos. Na hora, revelamos o diagnóstico, falamos de qualidade de vida, de medicação, de tudo... estávamos quase chorando na frente da paciente... ela ficou chateada, mas nem tanto quanto nós, ela disse que o marido havia morrido de aids. Então no fundo a gente acha que ela já sabia que estava infectada, mas que não havia procurado o teste antes por medo ou preconceito." - enfermeira.

Na fala da enfermeira, o fato de revelarem juntos o diagnóstico do HIV, o médico e a enfermeira, parece ter proporcionado maior segurança para os profissionais e usuária numa situação complexa, de compartilha de responsabilidade, preocupando-se em orientar, acolher e dar o melhor encaminhamento nessa situação.

Foi possível identificar que tanto o médico como a enfermeira estavam preocupados com o momento de revelação do diagnóstico. Apreende-se das falas que eles sofreram com a chegada do resultado positivo, mostrando empatia pela usuária. Segundo David (2002), o profissional pode também experimentar estresse emocional, resultante de seus próprios medos, preconceitos e conflitos relacionados aos diversos aspectos da aids. 
Na maioria das situações relatadas foi o médico da equipe o profissional que revelou o diagnóstico do HIV. Neves (2003) verificou que, embora não seja comum, em alguns serviços de saúde o diagnóstico do HIV foi revelado em conjunto pelo médico e a enfermeira.

O PSF tem como característica a articulação do trabalho entre os membros da equipe de saúde, construindo-se projetos de intervenção comum. Entre os membros da equipe houve a preocupação com os mitos e medos criados em torno da aids. E neste sentido, procuraram, nas ações desenvolvidas, desmistificar a doença, chamando a atenção para termos que comumente levam a discriminação e preconceito.

Como exemplo, tem-se na fala de um dos médicos entrevistados:

“... ela (usuária) sempre vem com as necessidades mais básicas como o preconceito da doença, a falta de conhecimento da doença. Gosto de ir tirando o preconceito através dos jargões, de usar os termos técnicos, minimizarem o impacto das palavras (...) eu tento tirar o estigma da doença (...) precisei mudar o conceito dos termos que a ACS falava. Expliquei sobre a carga viral, a orientação sexual, os termos de ser portadora ou ser paciente aidética. É importante fazer isso porque diminui o preconceito, como eu e a enfermeira não temos o preconceito, ela (ACS) aprendeu a não ter também." - médico.

De fato, na situação de revelação do diagnóstico de HIV, um dos pontos principais de intervenção, diz respeito ao sentimento de medo da doença, da morte e de preconceito que a usuária possa vir a sofrer.

Sobre o medo, Paiva (1992) argumenta que a construção social da aids a identifica como um perigo. O medo vem de uma suposta sentença de morte que está aliada ao diagnóstico da infecção pelo HIV. Decorre o medo da morte biológica, social e civil, além da morte de planos, sonhos e projetos para o futuro. Para David (2002), no momento de comunicação do diagnóstico, é importante que o profissional de saúde leve em consideração essas reações e informe sobre as novas possibilidades 
de tratamentos e recursos disponíveis que, se acessados, abrem outras expectativas de vida para as pessoas infectadas.

É comentado em um dos grupos focais o medo do preconceito que a mulher acha que vai sofrer se a família e a vizinhança souberem do seu diagnóstico de HIV.

Na questão do HIV/AIDS, segundo Parker e Aggleton (2002), preconceito, estigma e discriminação são assuntos bastante debatidos por causarem impacto na epidemia, especialmente ao dificultarem a prevenção de futuras infecções e as ações de assistência.

O preconceito, a discriminação e o estigma são distintos entre si, mas estão relacionados e contribuem para as relações sociais desiguais. Para Ritcher (2001) alguém que abriga o preconceito contra um indivíduo ou grupo, se fizesse uma ação com base nesse preconceito, estaria discriminando, por exemplo, um indivíduo, pois o estaria tratando de modo diferente de outras pessoas.

Entende-se que nas situações em que há o estigma ocorrem processos de rotulação ou esteriotipação, como em situações de discriminação nas quais estes processos se desenvolvem (Link e Phelan, 2001). O estigma sentido, além de dificultar a busca do diagnóstico, pode prejudicar o tratamento no tempo adequado e as ações de auto-cuidado, ou seja, o estigma sentido corresponde ao preconceito (Sontag, 1989). Já o estigma efetivado pode impedir indivíduos, grupos e sociedades de abordar adequadamente as questões de saúde, bem como nos serviços, como em instituições educacionais (D’Amélio et al, 2001). Portanto, o estigma efetivado relaciona-se aos atos de discriminação observados nas relações sociais injustas.

No estudo de Ferreira (2007), a autora comenta que a vivência das experiências de discriminação e preconceito ao longo da vida pode influenciar na abertura ou não da privacidade, como no caso da revelação do diagnóstico da aids. O sentimento de confiança que a mulher deposita nas pessoas com quem compartilha seu diagnóstico pode influenciar na decisão de contar (ou não) o que resulta na abertura (ou não) da sua privacidade.

“A minha paciente, assim que soube do diagnóstico, ficou com medo do preconceito (...), de como as pessoas iriam reagir (...) Hoje em dia ela tem 
um bom relacionamento com os vizinhos, todos perguntam se ela está bem e a ajudam”- ACS.

“Após a primeira consulta em que ela me contou que é positiva, fui marcando os retornos para ganhar a confiança dela.” - médico.

Após a revelação do diagnóstico do HIV para a mulher, o médico e a enfermeira sentiram que houve a necessidade de acolher a paciente e ganhar a sua confiança conforme a dinâmica de trabalho da equipe. A confiança que a usuária sente pelo profissional é fundamental na construção do vínculo; ambos, confiança e vínculo serão tratados posteriormente.

\subsection{ACOLHIMENTO E VÍNCULO NA ABERTURA DA PRIVACIDADE}

Apreende-se das falas dos membros da equipe do PSF que acolhimento e vínculo são determinantes para que se estabeleça a confiança entre estes e a usuária, pré-condição para que ocorra a abertura da privacidade das informações.

O acolhimento, enquanto processo, é constituído por um conjunto de atos distintos nos quais os sujeitos (trabalhadores da saúde) que os realizam são “determinantes e determinados histórica e socialmente no contexto das políticas sociais do país”. Esta é uma das abordagens que se relaciona com a descrição de que, o acolhimento é um processo de trabalho em saúde no qual o modo de ser feito é visto como um dispositivo analisador e de mudança (Matumoto apud Campos, 1998).

O acolhimento, como dispositivo de mudança, tem a autonomia como instrumento capaz de "instrumentalizar o conjunto de trabalhadores como gestores efetivos do processo de trabalho” (Matumoto apud Merhy, 1998). Nessa abordagem, o trabalhador de saúde é capaz de conduzir o processo de trabalho de modo humanizado, construindo assim mudanças na saúde. O trabalhador é o sujeito que 
transforma, constrói e reconstrói o quotidiano do trabalho. Para Matumoto (1998), o acolhimento é um processo que acontece em toda situação de atendimento, a partir da entrada do usuário no sistema e é de responsabilidade de todos os trabalhadores de saúde, ou seja, no desenvolvimento das práticas individuais ou coletivas.

Como processo, o acolhimeneto aproxima o serviço de saúde com a população atendida, favorece o estreitamento das relações entre os trabalhadores e usuários e assim, permite que o serviço de saúde consiga cada vez mais identificar e entender as necessidades de sua população.

Segundo Merhy e Bueno (1997), o acolhimento “passa pela escuta das necessidades do sujeito e pelo processo de reconhecimento e responsabilidade entre serviços e usuários, e abre o começo da construção do vínculo”.

Requer-se do trabalhador de saúde conhecimentos e habilidades para acolher, o que significa, abrir as portas de sua percepção, abrir-se para ajudar o outro, por exemplo, chamando-o pelo nome e enfatizando sua individualidade (Miranda, 1996).

Na prática dos serviços especializados de DST/AIDS são realizadas ações de aconselhamento que se confunde com a definição de acolhimento: "processo de escuta ativa, individualizado e centrado no usuário. Pressupõe a capacidade de estabelecer uma relação de confiança entre os interlocutores, visando ao resgate dos recursos internos do usuário para que ele mesmo tenha possibilidade de reconhecerse como sujeito de sua própria saúde e transformação” (Brasil, 1997).

O aconselhamento assim definido possui três componentes: o apoio emocional, o apoio educativo - que trata das trocas de informações sobre DST/HIV/AIDS, suas formas de transmissão, prevenção e tratamento - e, por último, a avaliação de riscos, que propicia a reflexão sobre os valores, atitudes e condutas, incluindo o planejamento de estratégias de redução de risco.

Os membros das equipes de PSF do estudo entendem que estes componentes devem estar presentes no processo de acolhimento da usuária portadora do HIV/AIDS. Destacam que uma questão central é o estímulo ao auto-cuidado, destacando especialmente a questão da importância do tratamento, do sexo mais seguro e outras ações de promoção da saúde e prevenção da infecção: 
“Eu procuro orientar bastante sobre o que a paciente tem e escutá-la (...) eu faço parte da manutenção do tratamento dela. Explico a importância da adesão aos medicamentos, falo da qualidade de vida, dos estudos, dos esportes (...).” - médico.

“Eu encorajo a paciente a ter uma vida normal, namorar, beijar na boca, ter relações sexuais, mas sempre com cuidado”. - ACS.

“É uma paciente que o parceiro é fixo na área, ambos são soropositivos”. Eles já se conheceram depois que ambos estavam com o HIV e estavam tendo relações sexuais sem o preservativo. "Nós tivemos que fazer um trabalho de conscientização e explicar que mesmo portadores do HIV devem usar o preservativo pelo risco da recontaminação." - médico.

Nos discursos dos entrevistados e nos grupos focais foram observadas diferentes definições para acolhimento. Segundo enfermeiras e auxiliares de enfermagem, acolhimento possibilita ao usuário "falar sobre o que sente e sobre suas necessidades”. É um espaço que proporciona escuta e auxilia na resolução de eventuais questões que preocupam o usuário.

Para Filgueiras e Deslandes (1999) o processo de escuta estabelece uma relação de confiança entre os interlocutores, visando que a pessoa atendida seja responsável pela sua própria saúde e transformação. Para David (2002) o profissional deve buscar, em parceria com o usuário, identificar as suas necessidades considerando e compreendendo suas emoções, sua realidade concreta de vida transmitindo-lhe confiança e respeito, e construindo as possíveis soluções para seus problemas.

Nas falas abaixo, destaca-se que o acolhimento é o ouvir, é oferecer para o usuário um momento só dele, no qual ele possa falar sobre suas necessidades.

“(...) para acolher precisa estar perto, conversar, orientar, ouvir (...) Acolher é dar orientação, apoio e esperança (...) É estar próximo, se a pessoa vem ao posto, perguntar o que ela precisa, tratar de um jeito especial (...) Eu procuro deixá-la á vontade e acolher da melhor forma possível" - enfermeira. 
“O acolhimento é escutar, é ouvir, mesmo que você não responda nada (...).” - AE.

“(...) conversar com ela entre aspas, porque ela que conversa, a gente só escuta. O que elas precisam nesta hora é de alguém para ouvir, orientá-las”- AE.

"No acolhimento eu procuro conversar com a paciente, ganhar a confiança dela e não pergunto muito porque a hora que ela quiser, ela vem e me conta”- ACS.

É observado no conteúdo das falas do ACS e da auxiliar de enfermagem que o acolhimento é necessário para detectar as necessidades dos usuários e para exercer as ações de saúde, e para a sua realização o profissional deve proporcionar um ambiente propício à escuta:

“... cabe ao ACS sentar e escutar para saber qual é a necessidade da pessoa. Às vezes a gente fica de mãos atadas para resolver tudo, mas só de conversar a paciente já se sente bem. Em geral todos os problemas são desabafados. A gente nem precisa falar nada, é só escutar”- ACS.

"Deve ser da maneira que o paciente deixa. Se a pessoa aceita da gente ir à casa, eu prefiro ir na casa porque é o ambiente da pessoa, e ela fica mais a vontade para falar. Eu deixo para o paciente escolher"- AE.

Segundo a auxiliar de enfermagem, o tempo de experiência profissional pode modificar a concepção sobre o que vem a ser acolhimento.

“Eu lembro que quando eu comecei a trabalhar aqui eu via que o acolhimento era quando você escutava o paciente e dava a resposta que ele queria ouvir. Hoje, depois de oito anos, eu vejo que nem sempre você precisa responder, é só parar para ouvir. Mesmo que depois de 20 minutos você diga que não pode fazer nada. Muitas vezes, a pessoa tira as respostas de sua própria fala” - AE. 
O acolhimento de uma mulher portadora do HIV, segundo uma enfermeira, não é diferente do acolhimento de qualquer outro usuário.

“... mas eu acho que essas mulheres (HIV) são iguais a todo mundo. Tem um diagnóstico diferente que direciona outras coisas, como estar de olhos mais abertos e espaçar menos as consultas. Mas o acolhimento é sempre igual, por exemplo, ao de um diabético descompensado, depende muito de como a pessoa está (...).” enfermeira.

Um dos médicos destacou o primeiro contato com a usuária como momento fundamental do acolhimento, quando dá se o início da relação e vínculo.

“O primeiro contato é muito importante para a gente ter empatia e o paciente se sentir acolhido.”- médico.

“A relação médico-paciente é uma relação terapêutica. Se essa relação é estabelecida de forma adequada, metade do caminho já foi percorrida. Porque a paciente vai se sentir mais confiante e acolhida, e vai com maior facilidade aderir ao tratamento.”- médico.

Nas falas anteriores, destaca-se que as relações entre as equipes de PSF e as usuárias, portadoras de HIV/AIDS devem ser acolhedoras.

Para Matumoto (1998), Humanização é entendida como o resgate do homem no processo de trabalho em saúde e que o trabalho humanizado é percebido como necessário ao desenvolvimento da essência humana. O acolhimento resgata valores de solidariedade, respeito com o outro, estabelecimento de vínculo entre os envolvidos, acesso aos serviços e, conseqüentemente, responsabilizando os profissionais de saúde pelos problemas da população e buscando construir caminhos para solucioná-los.

Alguns autores (Matumoto (1998) apud Scharaiber et al, 1996; Campos, 2000; Merhy, 2002) questionam a rotinização dos cuidados e a maneira impessoal como a assistência á saúde, é de um modo geral, realizada. Estes indicam a 
importância da superação desse modelo assistencial e defendem a Humanização na relação instituição-população.

Segundo a fala da auxiliar de enfermagem, o acolhimento no sentido de humanização é importante para o atendimento ao indivíduo HIV/AIDS, identificando sentimentos como, amor, carinho e respeito, elementos importantes na relação profissional-usuário.

“(...) e na humanização que abrange tudo, amor, carinho e respeito. São as três coisas que eu acho primordiais para um ser humano, não só acometido pelo HIV, mas em todas as doenças e todas as situações” - AE.

As ações de acolhimento fazem parte do processo de trabalho do PSF e são essenciais para o vínculo entre o profissional de saúde e o usuário/família seja construído. De fato, observa-se que os profissionais do PSF realizam essas ações e estão dispostos a contribuir pra as mudanças em saúde da comunidade.

Os profissionais entrevistados mostraram nas falas envolvimento profissional e afetivo com as mulheres portadoras do HIV e suas famílias. Referem terem se dedicado nas orientações de auto-cuidado, dialogando sobre promoção da saúde e prevenção das doenças, conduzindo grupos educativos e realizando visitas domiciliárias de forma a dar contemplar as necessidades de saúde das famílias.

“Eu faço o vínculo através do acolhimento (...) precisa estar perto, conversar, orientar e ouvir, perguntar o que ela precisa, tratar de um jeito especial.”enfermeira.

No PSF o vínculo com a família é condição para o desenvolvimento das ações num trabalho em equipe. Segundo Gomes e Pinheiros (2005), o seu estabelecimento do vínculo implica responsabilização e compromisso de ambos.

“Geralmente eu sempre tenho vínculo com a família (...) a família fala se existe alguém doente... nos dois casos (de mulheres com HIV) que tive, eu previamente já conhecia a família, mas não as duas mulheres, pois não moravam na casa” - ACS. 
“A questão do vínculo é muito ampla porque a gente não se relaciona só com o paciente, mas com toda a família. É feito um diagnóstico de saúde, de ambiente, familiar e individual (...) a gente se vincula a família (...).” - médico.

“A paciente mesmo eu só vi uma vez porque ela trabalha, mas tenho um vínculo muito bom com a família dela. Com ela eu ainda não consegui formar um vínculo (...) o médico fica mais com a paciente e eu (enfermeira) cuido mais da família." enfermeira.

O PSF deve conduzir os conflitos entre os interesses de um membro individualmente e dos outros integrantes da família. A ponderação de interesses dos diferentes membros individualmente e da família como um todo, pode constituir uma oportunidade para o fortalecimento dos laços familiares, desde que a decisão tomada resulte de uma discussão face a face entre todas as partes interessadas. Entretanto, isto não pode ocorrer como algo unilateral, imposto pela equipe de saúde, não importa quão benevolente sejam as intenções (Zoboli apud Brody, 1983b).

Na fala abaixo, a usuária deposita na profissional e, indiretamente em toda a equipe, a responsabilidade de revelar o seu diagnóstico de HIV para a família, o que indica que a usuária confia na equipe para ajudá-la no momento de revelação do diagnóstico. Tal proposta não é aceita pela auxiliar de enfermagem que refere que é uma ação que passa dos limites da relação profissional-usuário.

“Ela queria que eu contasse para a mãe dela, mas eu disse que era ela quem deveria contar”. Ela queria que a gente fizesse uma reunião com a família para revelar o diagnóstico (...) Eu acho que isso não está certo porque é muito vínculo, tem um limite” - $A E$

Na fala da auxiliar de enfermagem há um limite para o estabelecimento do vínculo, mas uma vez que o PSF tem como objeto de cuidado, a saúde das famílias, é importante a atuação da equipe na situação descrita acima, apoiando a usuária no momento de revelação do diagnóstico aos familiares, fortalecendo o vínculo. 
No relato do ACS, para a construção do vínculo são necessários tempo e paciência. Na fala da auxiliar de enfermagem, esta se faz especialmente nas visitas domiciliárias.

“(...) a gente leva tempo para criar vínculo, um dia você se apresenta, no outro diz oi, depois ela te convida para entrar na casa, leva tempo (...)”- ACS.

"Quando você cria vínculo com a paciente você consegue coisas que até Deus duvida. O vínculo mesmo você faz na casa e não no posto” - AE.

"Para mim é muito difícil trabalhar com ela porque muitas vezes ela bate o portão na minha cara e não me atende. Eu marco consultas e grupos, mas ela sempre falta. Mas eu não vou desistir dela, mesmo se ela bater o portão na minha cara...” - ACS.

“O ACS ia todo dia lá e com jeitinho foi tentando e conseguiu que ela tomasse a medicação"-AE.

Gomes e Pinheiro (2005) destacam a presença do ACS como parte integrante de uma rede de relações na comunidade e na equipe de saúde e como ator importante na promoção do vínculo. Os ACS possuem conhecimento dos aspectos relevantes do quotidiano da comunidade, diferentemente dos demais profissionais da equipe e acabam constituindo a ponte entre estes e a população, ajudando na identificação e na resposta às necessidades de saúde.

Para Merhy (1994:138) “criar vínculos implica ter relações tão próximas e tão claras, que nos sensibilizamos com todo o sofrimento daquele outro, sentindo-se responsável pela vida e morte do usuário, possibilitando uma intervenção nem burocrática e nem impessoal”.

Em uma das falas de um ACS o vínculo e o envolvimento nos cuidados com a sua comunidade podem trazer sofrimento ao profissional ACS.

“Ás vezes é ruim porque a gente se envolve muito e ai sofre. Com essa paciente foi assim, toda vez que ela passava na rua e me encontrava eu lembrava do 
HIV e aquilo me consumia, por ela estar de inocente na historia. O marido achava que o problema não era ele e sim as mulheres. Ele descobriu que era positivo e relutava, não queria encarar a verdade. No fim ele sabia e ela não. Ai você pensa que a mulher ta lá na casa, cuidando de tudo e dos filhos, e de repente cai uma bomba na cabeça dela... é difícil”. - ACS

A confiança e o vínculo estabelecidos no relacionamento entre o profissional e a usuária são condições para que haja a abertura da privacidade das informações sobre o diagnóstico de HIV aos membros da equipe de PSF.

"Se o ACS tem um vínculo, entra na casa, tem um contato de confiança e o paciente sabe que o ACS não vai contar para o resto da comunidade mesmo que esse ACS tenha crescido lá, ai o paciente se abre (...) e é com o vínculo que o paciente se apega á equipe” - ACS.

“Então se a pessoa pega um vínculo e se ela sente confiança, ela vai abrindo seus problemas, vai contando, mas tem que ter aquela confiança, você tem que ir conversando, dando orientação, incentivando a vida, e não é só porque você tem esse vírus que você vai deixar tudo, não, você pode continuar fazendo tudo, a mesma coisa, mas tendo cuidado, prestando mais atenção nas coisas que você vai fazer...”. -

“Eu expliquei a paciente sobre o sigilo no meu trabalho a após a conversa a paciente sentiu confiança”- ACS

“A paciente adquire uma confiança em mim e sabe que eu não vou ficar falando por ai"- ACS

A privacidade constitui o mecanismo de regulação do relacionamento entre os profissionais de saúde e os usuários, que pode facilitar o estabelecimento da confiança mútua necessária ao desenvolvimento do trabalho (Sacardo, 2001). 
Duas auxiliares de enfermagem identificam algumas condições que auxiliam no cuidado em relação à privacidade da usuária.

“Eu procuro levá-la em uma sala reservada, porque normalmente chegam, cochicham, então quer dizer que têm algum problema e que não querem falar na

frente de todo mundo. Eu vejo uma sala que está desocupada e chamo. Elas conversam, falam o motivo de estarem ali, se vieram pegar alguma medicação, se está faltando alguma coisa (...) Essas pessoas ficam muito sensíveis, então quanto mais a gente poder dar privacidade para elas, é melhor. Elas preferem a privacidade do que falar na frente de todo mundo porque as vezes pode ter um outro colega que não têm vínculo. Então eu procuro estar falando com ela, só ela e eu mesmo. Se elas vem procurar é porque precisam... se você orientá-las bem direitinho, a orientação que elas precisam, fica tudo bem. Também é o que eu falo, é que é outra vida que precisa aprender a viver, tem que aprender a lidar com esse lado da moeda que você não queria em sua vida, mas que acabou adquirindo.” - AE

Na abertura da privacidade é necessário que se estabeleça um acordo de confidencialidade, num certo sentido, "um pacto". A privacidade e a confidencialidade são princípios complexos que se correlacionam entre si. A privacidade consiste no conjunto de informações sobre uma pessoa, que pode decidir mantê-las sob seu exclusivo controle, ou comunicar, decidindo em que medida e a quem, quando, onde e em que condições o outro poderá acessar as informações. Já a confidencialidade se relaciona na garantia (no sentido de confiança) de que as informações confiadas não serão reveladas sem prévia autorização da pessoa em questão. Ou seja, a privacidade das informações é um direito dos usuários do serviço, ao mesmo tempo que a confidencialidade é um dever dos profissionais em relação às informações geradas e confiadas no relacionamento profissional-usuário (Massarollo, Sacardo e Zoboli, 2006) .

Em outro relato observa-se que a usuária decide se quer (ou não) confiar no profissional de saúde. Para que o usuário confie no profissional, a auxiliar de enfermagem relata que a confidencialidade das informações é fundamental. É 
importante que o sigilo das informações seja mantido para que a usuária freqüente o serviço de saúde.

“... só que há resistência, não é fácil. Não pense que eu convenço meus pacientes de um dia para o outro. Se eu disser isso eu estou mentindo, mas eu convenço, ganho a confiança e eles querem ganhar a confiança, querem se sentir seguros, que aquele chão que eles está pisando não vai afundar, que as informações que estou colhendo não vão vazar. Se não houver o vinculo da confiança e do respeito, geralmente eles nem colocam a cara aqui. Mas eu consigo sempre convencê-los, eu tenho facilidade nisso" - AE.

Uma auxiliar de enfermagem destaca que é necessário abordar diretamente a questão do sigilo e de que forma pode efetivamente apoiá-la.

“Em primeiro lugar, eu acho que o meu trabalho vai muito de cada um, pois nós entramos até na casa dos pacientes. Eu pessoalmente busco, estar sempre conversando, vendo a necessidade dela, ouvindo o que está faltando para ela, o que está incomodando naquele momento, se os outros sabem daquele problema ou se é para manter sigilo sobre o problema, o que posso fazer para amenizar a dor o sofrimento... e que ela tenha força para lutar. Hoje em dia só morre se a pessoa se recusar a se tratar, que é um direito dela. Se precisar eu busco em casa para realizar alguma atividade, eu quero que ela tenha integração social, se entrose, que conheça meu trabalho... E eu nunca vou tratá-la como um soro positivo, mas como a"Dona. "Maria”, paciente nossa, eu vou tratá-la como gente. Convidar para as atividades, é isso que é humanizar, não ver só como doença. É isso que o paciente quer, que você não a trate como um soro positivo. É assim que eu vejo, como ser humano. Não colocar como um estereótipo e marcar para o posto inteiro que ela tem HIV. Acho legal a pessoa ser normal, conviver com os outros normalmente, utilizar a unidade, participar das atividades"- AE. 
Num dos casos já relatado anteriormente, o vínculo estabelecido entre o ACS e a usuária, fizeram com que esta confie material pessoal para ser entregue a familiares.

“Ninguém da família dela sabe. Ela faz um diário e grava fitas para quando acontecer alguma coisa com ela, eu entregue tudo para a família. Ela tem medo da rejeição. Antes dela me contar ela disse que seu eu não quisesse mais falar com ela, tudo bem. Ai eu vejo como é difícil para ela. Ela toma todos os remédios, mas a família nem percebe”. - ACS.

A partir das ações de acolhimento e da construção do vínculo entre a usuária HIV/AIDS e o profissional de saúde, há uma aproximação entre ambos. Com isso, pode ocorrer a abertura da privacidade por parte da usuária, momento este em que a mulher pode ter o desejo de revelar ao profissional sobre seu diagnóstico de HIV, situações que serão abordadas a seguir.

\subsection{A REVELAÇÃO DO DIAGNÓSTICO DE HIV AOS MEMBROS DA EQUIPE DE PSF}

De acordo com os relatos nos Grupos Focais, nas entrevistas das auxiliares de enfermagem, das enfermeiras e dos médicos, foi a própria usuária portadora do HIV que freqüentemente revelou o seu diagnóstico aos membros da equipe de PSF. Portanto, as usuárias abrem a privacidade de sua informação às equipes.

Cabe aos profissionais de saúde estabelecerem condições para que o usuário possa decidir sobre quais informações quer manter em segredo, e quais quer comunicar aos familiares, amigos ou aos profissionais de saúde. 
Conforme já se apresentou anteriormente, a privacidade se refere ao limite dado pela usuária do serviço de saúde do que pode ou não ser compartilhado com outros, sejam eles profissionais da área da saúde ou não.

De acordo com Massarollo, Sacardo e Zoboli (2006), o "limite de acesso" às informações pessoais é dado pela pessoa autônoma. Segundo acrescentam, o conceito de privacidade das informações aparentemente se equivale ao de confidencialidade, no entanto, a confidencialidade diz respeito à responsabilidade dos profissionais em relação às pessoas que assistem.

A confidencialidade ou sigilo das informações traz ao profissional, o dever ético e legal de resguardá-las. Considera-se que para que o PSF possa planejar suas ações voltadas ao seu território é importante que conheça também famílias cujos membros estão infectados com o HIV.

Ferreira (2007) comenta que um dos motivos para que a decisão de revelar o diagnóstico à equipe está relacionada ao bom atendimento e acolhimento estando presente a confiança nos profissionais do PSF.

A confiança pode ser estabelecida ao longo do tempo pelos sujeitos que se relacionam. A confiança pressupõe honestidade, sinceridade nas atitudes e no diálogo, compartilhada pelo usuário e o profissional.

De fato, a confiança depositada no ACS foi identificada como um dos principais elementos que possibilita a abertura da privacidade, no sentido da revelação do diagnóstico.

Os ACS reforçaram em suas falas que a usuária revelou aspectos de sua vida privada e sobre ser portadora do HIV, na maioria dos casos, não de imediato, isto ocorreu somente após ter estabelecido de alguma forma um contato mais próximo com algum profissional da equipe e quando se encontrou num momento mais vulnerável de sua vida. Segundo Fortes e Spinetti (2004), existe por parte dos ACS, a preocupação em manter o sigilo profissional como princípio ético da privacidade.

“... ela era nova na área e eu sempre ofereci a conversa. Disse que a hora que ela quisesse poderia conversar comigo. Depois de um tempo ela se abriu e me contou que tinha HIV" - ACS. 
"Ela me disse que se tratava no CRT, ai eu ofereci a conversa, e um dia ela me contou que é soropositiva” - ACS “(...) ela se abre comigo, fala que o marido a trai” - ACS.

“Tem uma paciente que descobriu o HIV no pré-natal e não me contou. Ai eu só fiquei sabendo porque ela passou mal. Ai eu corri com ela para o hospital e ai ela me contou" - ACS.

Durante a rotina de visitas domiciliárias, os ACS ao terem suspeitado de que há algum portador de HIV abordaram o assunto sem falar diretamente, como nas situações descritas:

“Ela tinha acabado de dar a luz e não amamentava, perguntei o porque e ai ela me disse que fazia acompanhamento no CRT” - ACS.

“Eu suspeitava e ia perguntando... suspeitava porque ela casou muito nova e o marido é ‘macaco velho'. Ai ela se abriu comigo”-ACS

Avalia-se que esta estratégia teve um bom resultado, no sentido de que não se abordou diretamente a questão, deixando a usuária mais a vontade e se estabeleceu a confiança para que esta pudesse abrir sua privacidade em relação a sua vida e o seu diagnóstico.

Em outra situação, a usuária quis manter o segredo de seu diagnóstico a um dos profissionais da equipe, no caso, uma auxiliar de enfermagem por ela ser membro de sua família. Após ter sido reforçada pela médica a questão do sigilo das informações, a usuária sentiu-se mais segura para compartilhar seu segredo com esta profissional. A explicação sobre o dever do sigilo, esclarecendo para a usuária as questões sobre privacidade e confidencialidade reforçam a credibilidade nos profissionais (Ferreira, 2007). 
“Quando veio o resultado, ela falou para a médica que não queria que uma pessoa específica da equipe soubesse, e tudo indicava que era eu por eu ser da mesma família que ela. Às vezes eu a via chorando, mas não podia fazer nada. A médica disse para a paciente que todos os membros da equipe têm que ficar sabendo para que as ações fossem planejadas, e que ficaria só entre a equipe. Eu deixei bem

claro para ela que eu não iria contar para ninguém, quando ela se abriu comigo. Hoje ela está grávida e me procura para conversar. Ela tem confiança e sabe que eu não vou levar o caso para casa”- AE.

Conforme vem se discutindo, a confiança é um dos elementos que possibilita a abertura da privacidade dos usuários para os trabalhadores de saúde, e que na abertura da privacidade é primordial que os profissionais de saúde não revelem os segredos que lhe foram confiados (Almeida e Munoz, 1993).

“Eu e a rua inteira sabíamos que ela tinha, ela era minha velha conhecida. Escrevi a suspeita no meu relatório e o médico marcou uma consulta para ela. Na consulta ela se abriu com o médico. Ele disse a ela que poderia confiar em mim. Depois da consulta ela se abriu comigo e disse que já imaginava que eu sabia, mas que tinha vergonha de me contar. Ai eu disse para ela que agora seria mais fácil da gente conversar (...)” - ACS.

Em 2005, o PSF de Vila Penteado, devido a uma ampliação de suas equipes readequou sua área de abrangência. Desta forma, algumas famílias que eram assistidas por uma determinada equipe, passaram para outra. Este foi um momento em que houve compartilha de informações das famílias, inclusive sobre membros portadores do HIV.

Segundo os ACS, apesar de não ter sido discutida com a usuária a abertura da privacidade das informações, buscou-se guardar o sigilo destas entre as equipes. Compartilhar a informação foi, segundo a ACS, fundamental para a continuidade da assistência. 
“Esse caso era de outra ACS que me contou quando eu peguei a área. Depois de quatro meses a paciente me contou (...).” - ACS.

Na fala seguinte, destaca-se que a informação sobre o diagnóstico do HIV pode ter sido comentada entre os vizinhos e pela família da usuária. Os vizinhos, que também residem na área de responsabilidade do ACS, acabaram contando a ele sobre usuárias, possivelmente portadoras do HIV. As falas a seguir exemplificam estas situações:

“Eu tenho uma senhora na minha área com HIV, mas nem fiquei sabendo por ela, fiquei sabendo pelos vizinhos (...).” - ACS.

"Fiquei sabendo através da sogra porque a mulher era moradora de rua e veio para a área." - $A E$.

(...) fiquei sabendo por boatos nas ruas (...) ela tinha 16 anos e estava com um cara casado. A esposa dele morreu e ela engravidou, ela dizia que o amor por ele era maior que a aids. A gente até tentou que ela fizesse acompanhamento de pré-natal aqui e no Cachoerinha (Maternidade), mas ela faltava muito. Pedimos o exame do HIV mas ela não veio fazer (...) ai, a maternidade ligou e falou sobre o resultado positivo (“...)." $-A E$.

“Essa paciente não morava na área e eu fiquei sabendo pela irmã dela. Ela tinha se separado do marido quando descobriu que tinha HIV e achou que havia pego dele. Ai ela veio morar na casa da mãe e da irmã.” - ACS.

Fortes e Spinetti (2004) discutem que a organização do trabalho no PSF facilita que as informações sejam disseminadas, até mesmo as sigilosas. Segundo os autores, tal fato traz implicações éticas no que diz respeito à privacidade e a autonomia dos usuários (que engloba a intimidade, a vida privada e a honra das pessoas), especialmente no que tange a informações pessoais que possam trazer 
algum grau de discriminação e/ou estigmatização, em particular no caso de pessoas afetadas pelo HIV/AIDS.

Na fala abaixo, os profissionais perceberam situações em que pode ter ocorrido constrangimento e medo de discriminação da usuária.

“(...) nós estávamos indo fazer visita na casa dela direto (...) percebemos que a usuária não estava se sentindo a vontade porque não sabia dizer o que os vizinhos poderiam achar (...)”- enfermeira.

“(...) ela nem veio fazer o pré-natal aqui para evitar os comentários (...)”enfermeira.

Conforme vem se discutindo até aqui, além do diagnóstico de HIV ter sido revelado aos membros das equipes pela própria usuária portadora da infecção, também esta informação chegou através dos vizinhos e seus familiares.

Uma outra forma com que a informação chegou aos membros das equipes é através dos serviços de referência.

Numa das falas, por exemplo, uma auxiliar de enfermagem soube do diagnóstico de usuárias do PSF através da informação que veio de dois serviços de referência:

“Uma vez eu fiquei sabendo através do Emílio Ribas que entrou em contato. A outra, pelo CRT." - AE.

Os serviços de referência, ao oferecerem ao usuário HIV/AIDS atendimento diferenciado realizado por uma equipe multidisciplinar especializada que tem qualificação para diagnosticar e acompanhar o tratamento dos casos e que realizam também a investigação dos casos, como o controle de comunicantes, e faltosos e o preenchimento da Ficha de Investigação. Desta forma não há praticamente ações de vigilância epidemiológica sob a responsabilidade da Atenção Básica. (Silva et al, 2005). E diferentemente de outros agravos agudos e de rápida disseminação, como a dengue, a meningite o sarampo e até a tuberculose, na aids não há um fluxo de 
informações dos casos realizados de forma rotineira dos serviços de atendimento especializado e o PSF.

No entanto, dentre as discussões que vem sendo realizadas em relação a ações de prevenção e assistência ás DST/AIDS na rede de atenção básica, destaca-se a importância que o PSF vem assumindo, no sentido de ampliar suas ações para os grupos vulneráveis a infecção e aqueles que já se encontram infectados. Diante disso, é importante que se estabeleçam mecanismos de comunicação entre os diferentes serviços da Atenção Básica e serviços especializados, desde que sejam garantidos a privacidade e o sigilo sobre a condição do usuário.

Outras fontes de revelação da informação aos membros das equipes foram relatadas, quando a auxiliar de enfermagem viu o resultado de exame laboratorial e quando leu no prontuário. Um dos médicos questiona que muitos exames chegam abertos. Para Sacardo e Fortes (2000) com relação ao uso das informações eletrônicas, são necessárias barreiras para que as pessoas, mesmo pertencentes ao quadro de funcionários do estabelecimento de saúde, não possam acessar informações sigilosas dos usuários sem que exista clara necessidade em benefício do usuário.

“Eu fiquei sabendo pelo prontuário. Eu fui medicar a paciente e li no prontuário.” -

“Ás vezes eu pego os resultados para separar e vejo. Ultimamente os exames estão vindo abertos, sendo positivos ou negativos, então acabo olhando os resultados." -

“Tenho problemas com os exames que chegam abertos, até chegar em mim já passou na mão de muita gente.” - médico.

Buscando identificar de que forma os membros das equipes conheceram a informação sobre o diagnóstico de HIV de usuárias foi construído o Fluxograma 2 abaixo, que resume o fluxo de chegada da informação. É importante salientar que foram retiradas das falas as situações em que pela primeira vez a informação chegou 
ao conhecimento do profissional, não sendo representado no fluxograma o compartilhamento posterior da informação entre os membros da equipe.

Fluxograma 2: Fluxo da informação do diagnóstico do HIV aos membros das equipes de PSF.

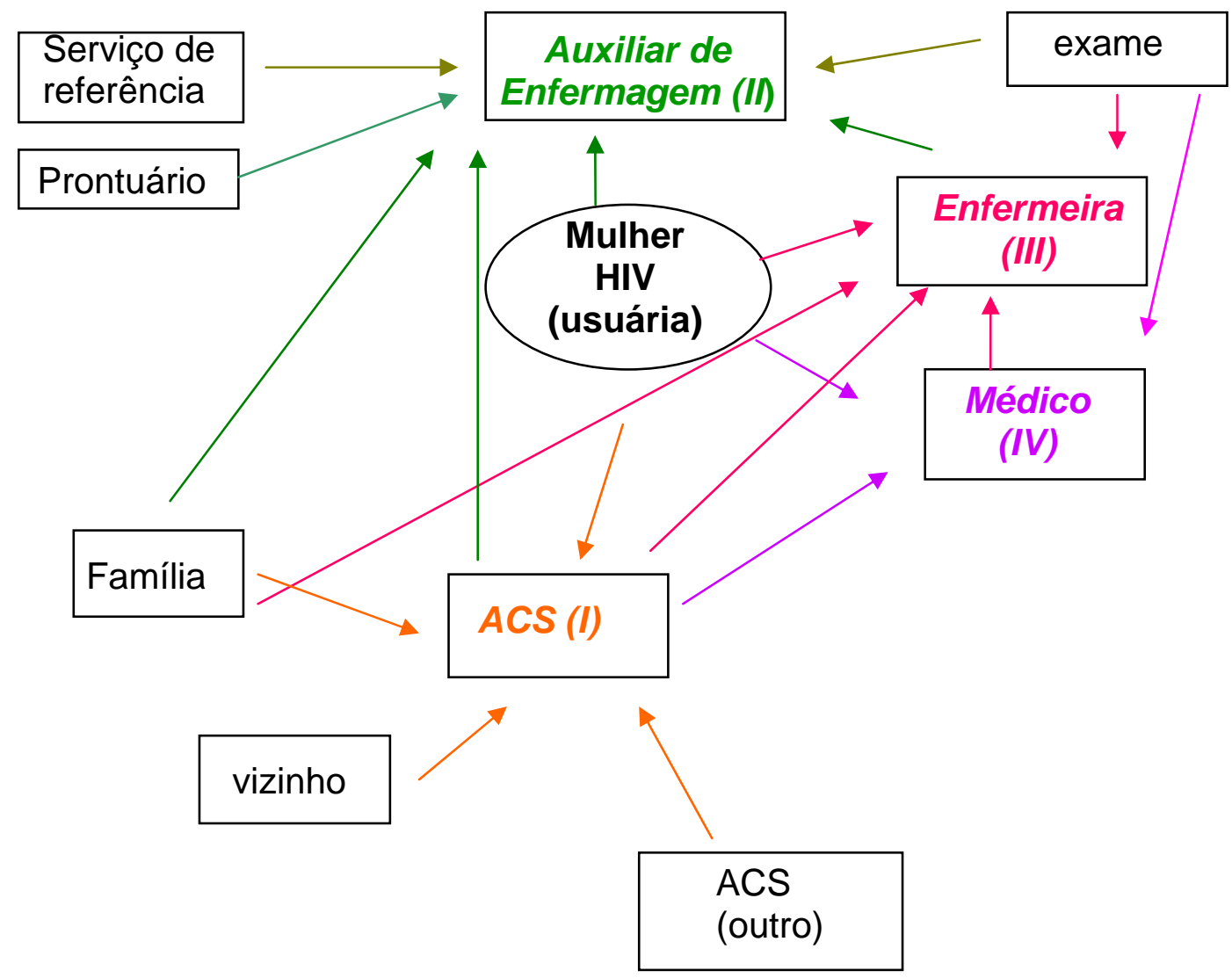

I- $\quad$ O ACS sabe do diagnóstico do HIV pela da usuária, pelos vizinhos, pela família, por outro ACS.

II- $\quad$ A auxiliar de enfermagem sabe do diagnóstico do HIV pela usuária, pelo ACS, pela família, pelo exame, pelo prontuário, pelo serviço de referência, pela enfermeira.

III- A enfermeira sabe do diagnóstico do HIV pela usuária, pelo ACS, pela família, pelo exame, pelo médico.

IV- O médico sabe do diagnóstico do HIV pela usuária, pelo prontuário, pelo exame, pelo ACS. 
Pelo fato de que ambos profissionais realizam suas atividades, na sua maioria, na própria UBS, pode explicar o menor número de fontes de informação a que eles têm acesso.

Após a revelação do diagnóstico de infecção do HIV aos membros da equipe houve situações em que foi compartilhado no interior da equipe e que serão tratadas a seguir.

\subsection{DISCUSSÃO EM EQUIPE E O SIGILO DAS INFORMAÇÕES}

As auxiliares de enfermagem e as enfermeiras destacam que as discussões em equipe, não só no HIV/AIDS como em outras questões, são diferenciais na prática do PSF. As discussões promovem envolvimento dos profissionais das equipes com os usuários e suas famílias.

O profissional médico relatou que é importante discutir os casos de mulheres HIV positivas para que haja a “democratização das idéias” já que o PSF trabalha com a dinâmica da equipe. Também é comentado pelos ACS que tudo é discutido em equipe porque a dinâmica do trabalho sugere que "deve-se pensar em equipe".

As necessidades de saúde identificadas junto às famílias são discutidas no interior da equipe, antes mesmo do conhecimento sobre o diagnóstico de HIV. Como exemplo, nas famílias vulneráveis ao uso de álcool e drogas, famílias em situações de conflitos.

“A gente já discutia o caso dela, já tinham problemas. Discutíamos a questão do alcoolismo, da família (...).” - AE.

“(...) discutíamos o caso antes... a mãe dela morreu há pouco tempo, o filho ta preso, o outro filho matou um cara (...)." - enfermeira. 
“Nesse caso a questão do alcoolismo foi uma porta de entrada para a gente se relacionar. Foi aí que a gente falou, olha não ta legal, vamos marcar uma consulta e pedir os exames, conversar (...).” - enfermeira.

Vale destaque, estas são situações de difícil abordagem pelas equipes, necessitando muitas vezes de um trabalho de acompanhamento das equipes de Saúde Mental, sendo esta participação, um diferencial importante na organização do processo de trabalho deste PSF e no cuidado dos portadores do vírus.

“A equipe pensa nas necessidades de saúde junto com a Saúde Mental, é um trabalho de parceria.”- $A E$.

“Então, a gente ainda vai discutir esse caso com a Saúde Mental. A gente vai discutir mais ainda o caso porque não é porque ela foi encaminhada para o DST (CRT) que pronto e acabou... muito pelo contrário. Ainda vamos á casa dela com a Saúde Mental." - enfermeira.

“Na visita domiciliar conversamos com toda a família para que esta ‘supervisionasse' o casal (ambos soropositivos) para que pudéssemos ter uma certa segurança de que a família estava se comprometendo no tratamento. A saúde mental também ajudou”.- enfermeira.

Conforme vem se discutindo anteriormente, a partir do conhecimento da informação sobre o diagnóstico de HIV por algum membro da equipe, de um modo geral este compartilha com o restante do grupo. Isto ocorre em vários momentos de discussões sejam no espaço formal de reunião de equipe, seja em outro onde se discute as demandas das famílias. Dessa forma, os casos de mulheres HIV acabaram sendo de conhecimento de todos os membros da equipe e segundo se identificou no estudo, há preocupação em relação ao sigilo, no sentido de que outras equipes do PSF não conheçam estes casos. 
“(...) fiquei sabendo pela enfermeira da equipe.”- $A E$.

“O ACS trouxe o caso e todos ficaram sabendo."- AE.

“Quem me contou sobre a mulher ter HIV foi o ACS (...).”- AE.

“(...) discutimos o caso mas fica entre quatro paredes.”- ACS.

“(...) discutimos (o caso) na reunião mas fica só entre nós.”-AE.

“(...) a gente discute tudo nas reuniões mas nada sai de lá(...).” - enfermeira.

“Nada sai da equipe, não só o HIV como qualquer outra coisa. Temos que preservar a paciente."- médico.

Justifica-se a discussão dos casos de HIV/AIDS, segundo os profissionais, para que haja maior envolvimento com as realidades das famílias, de tal forma que a responsabilidade sobre o seu cuidado não recaia sobre um determinado ACS, o médico, o enfermeiro e o auxiliar de enfermagem. Dessa maneira, o planejamento da assistência é compartilhado entre todos os membros da equipe.

“(...) nas reuniões de equipe sempre perguntam dessa paciente.”- ACS.

"Todos da equipe sabem do HIV porque se acontecer alguma coisa com ela, todos podem ajudar."- ACS.

Apreende-se das falas acima que muitas vezes ocorre abertura da privacidade e o compartilhamento das informações sobre mulheres HIV/AIDS entre os membros da equipe de PSF e equipe de Saúde Mental, sem que tenha ocorrido o consentimento ou autorização prévia da usuária para que isto tivesse ocorrido. 
De fato, observa-se na prática das equipes, que de um modo geral, não se discute especificamente as implicações da abertura da privacidade e confidencialidade das informações com as famílias, não só nas questões referentes ao HIV/AIDS como outras, identificadas no processo saúde-doença das famílias.

Entende-se que cabe aos profissionais de saúde discutir previamente com os usuários para que haja o consentimento da abertura da privacidade e compartilhamento das informações com os demais membros da equipe.

Numa outra situação, um dos médicos relata que após explicar a dinâmica de trabalho do PSF foi perguntado à usuária sobre a possibilidade de abertura do seu diagnóstico aos outros membros da equipe.

“Eu sempre explico para a paciente os princípios e a dinâmica do PSF, se ela se importa que os outros membros da equipe possam saber do seu diagnóstico (...) existem os dois casos na equipe, da paciente que prefere que os outros membros da equipe, com exceção da enfermeira e do ACS, não saibam e, da paciente que deixou aberto para todos sobre ser portadora do HIV e que não se importa que os outros membros da equipe saibam.” - médico.

Para Fortes e Spinetti (2004), o PSF caracteriza-se pelo vínculo e pela responsabilidade da equipe em relação às famílias de sua área de abrangência e salientam que é necessário o estabelecimento de contratos de manutenção do sigilo por parte das equipes em relação aos usuários.

É importante que o profissional explique aos usuários o processo de trabalho do PSF, as práticas que envolvem as discussões dos casos e os propósitos dessas discussões, incentivando para que o usuário veja a equipe de PSF como uma possibilidade de apoio, não se restringindo a um único membro.

Segundo os ACS, algumas vezes discute-se a manutenção da privacidade com a usuária. Por exemplo, uma mulher solicitou que algumas de suas informações não fossem anotadas no relatório do ACS. Este exemplo mostrou que a usuária nem sempre quer abrir sua privacidade, não só em relação ao diagnóstico do HIV, mas sobre outras informações que julga serem importantes na sua vida. 
“Às vezes a paciente não quer nem contar coisas para a equipe e pede que a gente nem anote (...)."-ACS.

A abertura da privacidade da informação pela usuária à equipe de PSF está baseada na confiança estabelecida. Segundo a auxiliar de enfermagem, ao abordar o assunto com a usuária sobre a manutenção do sigilo, estabelece-se uma relação de confiança. Almeida e Munoz (1993) ressaltam que a relação usuário-profissional é baseada na confiança mútua.

"Eu expliquei para a paciente que eu não ia contar para ninguém porque esse é o meu serviço. A gente conversou bastante e ela sentiu confiança em mim.” -

Em outra fala, o auxiliar de enfermagem refere que manter o sigilo é o mesmo que manter o respeito pelo usuário. Ao manter guardado o segredo do usuário, está ao mesmo tempo, respeitando as suas decisões.

“(...) manter o sigilo é o mesmo que manter o respeito pelo paciente (...).” -

AE.

Um dos médicos comenta sobre a diferença do uso do sigilo, vivenciada num serviço de saúde diferente do modelo de PSF. Nos serviços de saúde em geral as informações sobre o usuário ficam restritas apenas ao médico; já no PSF é condição do trabalho das equipes de PSF o compartilhamento e discussão sobre as informações e os fatos referentes aos usuários.

“Todos discutiram o caso na equipe. Existe o sigilo profissional na área médica quando estamos trabalhando num ambulatório convencional, ou seja, só o paciente e o médico ficam sabendo. No caso do PSF muda um pouco. É preciso comunicar á equipe o que está acontecendo e ao mesmo tempo zelar pela ética. A equipe precisa saber para democratizar... Na teoria é como se eu não contasse para ninguém, nem mesmo para o ACS, não posso colocar em risco a confiança do 
paciente. Uma vez veio a família da paciente me perguntando sobre o diagnóstico, mas eu não contei porque é um direito da paciente pedir sigilo. Uma vez a auxiliar me perguntou porque eu não contava o diagnóstico para a família para ver se levavam a paciente para o CRT, ai eu disse não. Quando a paciente dá autorização ao médico para contar as outras pessoas, tudo bem, mas do contrário não.” médico.

Há situações em que não há o compartilhamento da informação sobre o diagnóstico de mulheres acometidas pelo HIV/AIDS com todos os membros da equipe. Os membros ponderam sobre a necessidade de abrir para toda a equipe o conhecimento sobre algum caso de HIV, discutem que deve envolver somente aqueles que diretamente podem de alguma forma contribuir com as ações de assistência.

“Acho que compartilhar com as pessoas que não estão lidando com isso é desnecessário, não precisam ficar sabendo. Não tem necessidade de expor a paciente, a não ser para os profissionais que irão contribuir de alguma forma. Mas na equipe em geral é discutido.”- enfermeira.

“... eu sabia que o parceiro da paciente era soropositivo e que a ela não sabia disso. Aí eu discuti o caso apenas com a médica da equipe que decidiu conversar com o parceiro em consulta médica. Depois o casal voltou junto à consulta.”- ACS.

“(...) o ACS levantou a suspeita na reunião de equipe e depois que terminou a reunião, conversamos eu, o ACS e a enfermeira (...) eu até poderia ater discutido o caso com toda a equipe, mas é uma questão de sigilo com a paciente.” - médico.

A manutenção da confidencialidade do segredo, sigilo, por todos os elementos da equipe deve ser feita, lembrando que são sigilosas não somente as informações reveladas confidencialmente, mas todas aquelas que a equipe de saúde 
descobre no exercício de sua atividade, mesmo havendo desconhecimento do usuário (Fortes e Spinetti, 2004).

A partir do dever de todos os integrantes da equipe manterem segredo decorre o direito que o usuário tem à privacidade. Sem a garantia da confidencialidade, na maioria das circunstâncias, o usuário não se sentiria à vontade para revelar à equipe de saúde informações relevantes, mas que são potencialmente embaraçosas ou mesmo não teria confiança para comparecer aos atendimentos com vistas à avaliação e tratamento (Zoboli apud Halevy, 2000).

Todas as informações que o profissional do PSF recebe durante o exercício de suas atividades, seja na UBS ou nas visitas domiciliares, são sigilosas, e a confidencialidade dessas informações garante a manutenção e a melhoria progressiva do relacionamento do profissional com o usuário, fortalece o vínculo e traz á tona uma atmosfera de confiança entre eles.

Com freqüência o ACS tem conhecimento sobre o diagnóstico do HIV, mas a usuária não sabe disto. Nas conversas com a usuária, o ACS não deixa transparecer que sabe do diagnóstico, alegando que é uma questão de “ética”, não poder falar. Para manter a sua privacidade, a usuária fala apenas dos sintomas da aids, sem revelar seu diagnóstico, por sua vez, o ACS aborda o assunto de maneira a não identificar sua situação de portadora.

“(...) ela não sabe que eu sei (...) mas o mais engraçado é a gente ter a nossa ética de não poder falar. Ela conversava muito comigo, falava de coisas que aconteciam no corpo dela, mas eu não podia falar nada. Ela não sabe que eu sei.”-

ACS.

Em uma das falas de uma auxiliar de enfermagem, a usuária não sabe que a equipe de PSF também compartilha do conhecimento de seu diagnóstico de HIV, e recebe a assistência em saúde como qualquer outro usuário.

“(...) eu vou na casa dela, faço as visitas, trato como os outros pacientes (...) a paciente nem sonha que a gente sabe (...).”-AE. 
Além disso, este profissional salienta que as usuárias com HIV nunca solicitaram explicitamente da equipe que haja sigilo frente ao diagnóstico, mas mesmo assim refere que o sigilo é mantido.

"Ela nunca chegou e pediu para a gente não contar para ninguém, mas isso não significa que a gente conte (...) tudo fica só entre a equipe.” - AE.

A preocupação com a preservação da confidencialidade recai particularmente sobre o ACS, por este residir na área de abrangência de sua equipe. Dentre suas atribuições, encontra-se "não divulgar informações recebidas durante as visitas domiciliares a quaisquer pessoas que não pertençam à equipe de saúde”. Silva e Dalmaso (2002) sugerem que talvez por esta razão, o próprio agente reconheça como características para trabalhar na função “ser discreto” e não “falar da vida alheia”.

Para Neves (2003) a revelação do diagnóstico de soropositividade não deve ser feita sequer para os familiares se assim o usuário desejar. Existem casos em que a usuária é resistente em revelar seu diagnóstico para a família, pois quer manter sua privacidade. Neste caso o ACS age como se não soubesse do diagnóstico para que a família não perceba e comenta que sofre com isso, o que pode indicar o envolvimento do profissional com a usuária e a família.

"Eu tive um caso que foi bem complicado porque ela foi a óbito, e eu sabia do HIV mas a família não. E ela tinha acabado de dar a luz mas não amamentava, eu perguntei o porque e ai ela contou que fazia tratamento no Emilio Ribas, ela fazia o tratamento certinho. Quando ela começou a perder peso e se sentir mal, a família me pressionava para contar, eu sofri muito e chorava, mas não contei." - ACS.

Segundo Sacardo (2001) a família ocupa lugar especial na assistência ao usuário, pois em geral um dos membros assume o papel de “cuidador”, que desencadeia sentimento de segurança e diminui a sensação de vulnerabilidade ao adoecimento. Há pouca expectativa com relação à manutenção da privacidade entre a família e o usuário, e em geral é com o cuidador que o usuário pode optar por revelar 
aspectos e fatos de sua vida e sua situação de saúde. Acrescenta que cabe ao profissional de saúde atender as expectativas do usuário frente suas decisões, e não substituir a opinião da família pela opinião do usuário.

O ACS, a auxiliar e a enfermeira comentam casos em que a família da usuária portadora do HIV pressionou a equipe para que esta abrisse sua privacidade, questionando sobre o conteúdo do diálogo ocorrido entre o médico e ela. Os profissionais mantiveram o sigilo sobre o diagnóstico, mesmo nestas situações.

"A família começou a me pressionar e perguntar, eu disse que o que o médico e a paciente conversam é só entre os dois.”- ACS.

“... porque a família também fica pressionando a gente. Eles falam que o médico disse que ela pode morrer (...) mas a gente não abre o jogo.”-enfermeira.

Zoboli apud Halevy (2000) adverte que os profissionais na atenção básica devem estar alertas para os potenciais problemas na preservação da confidencialidade, com vistas a sua prática diária. A maioria dos usuários tem família e amigos que estão interessados em seus cuidados, esposas, filhos, "primos curiosos", "vizinhos bisbilhoteiros” e vários "melhores amigos”.

A equipe do PSF deve ter o máximo de discrição e discernimento ao escolher o que deve ser revelado e para quem. Deve-se procurar saber junto ao usuário quais são seus desejos quanto à revelação de informações suas para a família e amigos, não cedendo à insistência de quem procura saber algo. Especialmente no caso de HIV/AIDS, este é um assunto a ser tratado com a própria usuária.

“... a casa é tipo um cortiço e para chegar lá tem que passar pelas casas de todos os familiares que não sabiam que ela era portadora do HIV (esposa e marido têm o vírus). A família até suspeitava mas não sabia. Eles queriam saber da gente o que ela (mulher) tinha. Ai a gente falou que ela estava precisando se cuidar, se alimentar... não podíamos contar porque o paciente tem confiança na gente.” - AE. 
A enfermeira reforça aos ACS e demais membros da equipe a importância de não revelar informações dos usuários para pessoas que não são da equipe e para os familiares.

“Ninguém comenta nada com ninguém fora da equipe. E eu mesma reforço isso, até para não comentarem com alguém da família." - enfermeira.

Em um dos casos apenas o ACS sabe do diagnóstico, a família não. A usuária deixa sob responsabilidade do ACS algumas fitas cassete gravadas e diários escritos para que o ACS entregue tudo para a família caso aconteça alguma fatalidade com ela.

“(...) Ninguém da família sabe. Ela faz um diário e grava fitas para quando acontecer alguma coisa com ela, eu entregue tudo para a família. Ela tem medo da rejeição (...) antes dela me contar ela disse que se eu não quisesse falar com ela depois disso, tudo bem (...) ai eu vejo como é difícil para ela.” - ACS.

Em algumas situações, segundo as falas dos sujeitos de pesquisa, quando a família sabe do diagnóstico pode de alguma haver apoio. Quando a família sabe do diagnóstico do HIV e existe o apoio, há melhor qualidade do diálogo e da escuta terapêutica e esta participa das ações de saúde planejadas em equipe.

“Ela não faz tratamento nenhum (...) a mãe sabe do HIV e vem me contar sempre que ela não está bem.” - ACS.

No estudo de David (2002) as reações dos familiares e dos amigos frente ao portador do HIV, especialmente na fase inicial do diagnóstico, foram consideradas como determinantes das mudanças das suas reações iniciais, desencadeando comportamentos de enfrentamento positivo do processo instalado.

Silveira e Carvalho (2002) mostram que a família, peça fundamental no tratamento, ao se propor a cuidar do familiar atingido pelo HIV enfrenta problemas como as dificuldades em lidar com o aparecimento da sintomatologia. Para que a 
família possa ajudar é preciso que a equipe de saúde se proponha a ajudá-la nas dificuldades que surgirem ao longo do desenvolvimento da doença. E essa ajuda pode iniciar-se na escuta do familiar/cuidador num trabalho grupal. O familiar mostra-se aliviado ao desabafar seus medos e preocupações e sentir-se apoiado pela equipe de saúde.

Em uma das situações que mostra uma experiência positiva sobre a revelação do diagnóstico, relatada por Ferreira (2007), a usuária comentou que recebeu apoio da família após revelar seu diagnóstico, afirmando que isto á aproximou mais de seus familiares.

No mesmo estudo de Ferreira (2007), nas situações em que a usuária revelou seu diagnóstico de HIV a amigos, membros da igreja e familiares, observou experiências negativas nas quais houve falta de apoio, rejeição e de alguma forma a disseminação das informações a outras pessoas sem a autorização da usuária.

Por outro lado, houve relatos de situações em que não houve o apoio da família. Para Figueiredo et al (1996), o diagnóstico da aids pode contribuir com a desagregação familiar já instalada ou ser ela também desencadeadora desta condição.

O conhecimento sobre o diagnóstico de HIV pela família traz uma outra questão, por ser doença sexualmente transmissível, implica comunicantes e por isso embora como lembram Almeida e Munoz (1993), apesar do sigilo ser preconizado inclusive nos Códigos de Ética profissionais, sua manutenção é bastante complexa.

Um dos médicos comenta sobre a necessidade de estimular a abertura da privacidade pela mulher portadora do HIV ao parceiro que não sabe sobre o diagnóstico. Este destaca que, deve-se procurar convencer a usuária a contar sobre o diagnóstico de soropositividade ao parceiro ou se colocar à disposição para procederem juntos no momento de revelação.

“Quando a paciente é soropositiva e está tendo relações sexuais com o parceiro que não sabe do diagnóstico, ai cabe ao médico ter a sutileza necessária para forçar a paciente a contar para o parceiro, como já aconteceu com umas das minhas pacientes. No fim ela contou para o parceiro mas mesmo assim não usam o preservativo.”- médico. 
Esta conduta parece correta, na medida em que é recomendada pela Vigilância Epidemiológica que devem ser estimulados a colaboração e o consentimento da usuária, ela própria revelando sua condição aos seus comunicantes, bem como colocando-os em contato com o serviço de saúde (São Paulo, 1995).

Nas situações em que não houver colaboração da usuária para a revelação do seu diagnóstico para o comunicante, está previsto que o serviço de saúde poderá quebrar o sigilo, entrando em contato com aqueles que estiverem sob risco de infecção. Neves (2003) lembra que nestes casos é importante que o profissional registre todos os procedimentos realizados no prontuário do usuário, servindo como respaldo para o profissional.

Como já discutido anteriormente, a informação sobre o diagnóstico do HIV da usuária foi compartilhada com todos os membros da equipe de PSF e com a equipe de Saúde Mental quando necessário. Os profissionais de saúde relataram manter confidencialmente as informações da usuária. Contudo, é importante que o profissional de saúde estimule a usuária a consentir sobre o compartilhamento da informação sobre seu diagnóstico e a abertura da sua privacidade para os profissionais de PSF. 


\section{CONSIDERAÇÕES FINAIS}

As situações que envolvem questões de privacidade e sigilo das informações nas experiências de assistência às mulheres portadoras de HIV/AIDS, vivenciadas pelas equipes do PSF foram analisadas segundo quatro temas: a) a revelação do diagnóstico de HIV para a usuária; b) acolhimento e vínculo na abertura da privacidade; c) a revelação do diagnóstico de HIV aos membros da equipe de PSF e, d) discussão em equipe e o sigilo das informações.

O primeiro tema, a revelação do diagnóstico de HIV para a usuária, refere-se às situações que fizeram com que o(s) membro(s) da equipe suspeitasse(m) da infecção e indicasse(m) a realização do teste sorológico, e como se deu o momento de revelação para a usuária.

Os relatos dos sujeitos de pesquisa mostraram que a solicitação do teste de detecção do vírus partiu do profissional médico ou enfermeira, quando havia sintomatologia da infecção, pela história de vida da usuária e/ou alguma indicação de “comportamento de risco”.

Em outras situações os ACS foram aqueles que primeiro suspeitaram de uma possível infecção e depois levaram esta preocupação aos demais profissionais. Desta forma, os ACS possuem papel fundamental no apoio à detecção precoce de casos na comunidade.

Outras situações de pedido de realização do teste para detecção do vírus aconteceram nos atendimentos de pré-natal. A detecção precoce de gestantes HIV tem se mostrado como uma das ações que pode reduzir as chances de transmissão da infecção da mãe para o filho e deve ser precedido pelo aconselhamento. Para sua realização há necessidade de capacitação e orientação dos profissionais, para que entendam a importância deste para o estabelecimento de vínculo com a usuária.

Considera-se que o aconselhamento para a realização do teste anti-HIV pode ser realizado em outras situações de atendimento que não só de pré-natal, tais como, consultas médica ou de enfermagem, coleta de papanicolaou, visitas domiciliárias, grupos de planejamento familiar, etc. É fundamental que os profissionais não deixem 
de realizar o aconselhamento em todas as situações para que o usuário sinta-se bem esclarecido e seguro para aceitar (ou não) realizar o teste.

A ausência da procura espontânea pelo teste anti-HIV nos relatos pode indicar desde o desconhecimento sobre a possibilidade de realização do teste anti-HIV, como a existência do medo de enfrentar um possível diagnóstico e da discriminação que poderão sofrer caso haja a comprovação da infecção. De qualquer maneira, considera-se que os profissionais de saúde do PSF devem abordar temas que envolvem a aids, como preconceito, estigma e solidariedade, com as famílias e sua comunidade. Os temas devem estar incluídos nas ações já planejadas e desenvolvidos pela equipe de PSF.

As equipes podem ainda executar ações que desenvolvam habilidades de busca e recepção de apoio social, fortalecimento de vínculos familiares e sociais na assistência e convivência com as pessoas acometidas pelo HIV/AIDS. Considera-se que as equipes de PSF podem assumir o compromisso de buscar estratégias para a redução do preconceito e da discriminação com pessoas portadoras do HIV/AIDS.

Na revelação do diagnóstico do HIV à mulher, as situações relatadas mostraram que é interessante quando há parceria do médico com a enfermeira da equipe. O trabalho em parceria pode trazer maior segurança à usuária neste momento delicado. Ela pode sentir-se mais a vontade para falar sobre seus medos, suas incertezas, dúvidas e encontrar maior apoio para sua assistência. Além disso, compartilhar da responsabilidade sobre a revelação do diagnóstico entre os profissionais pode trazer segurança e apoio mútuo, favorecer o esclarecimento de dúvidas e discutir condutas a serem tomadas.

Considerando o princípio da autonomia, a mulher portadora do HIV/AIDS tendo a capacidade de decidir por si mesma nas questões que dizem respeito a si própria, como indivíduo, deve decidir se quer contar ou não o seu diagnóstico à equipe de PSF, ou seja, abrir ou não a privacidade desta informação. Ao mesmo tempo, entende-se que para que haja o planejamento e o desenvolvimento das ações específicas à mulher HIV/AIDS e aos membros das famílias sob responsabilidade das equipes, é necessário que haja a abertura de sua privacidade. E isto deve ser estimulada pelos profissionais do PSF. São condições para a abertura da privacidade 
da informação as ações de acolhimento que auxiliam na construção do vínculo e no estabelecimento da confiança.

Das falas dos sujeitos de pesquisa foi identificado o segundo tema, Acolhimento e vínculo na abertura da privacidade, e nas situações analisadas, de fato, as ações de acolhimento permitem a construção do vínculo e estabelecimento da confiança na relação entre o profissional, o usuário e as famílias.

O acolhimento deve fazer parte do atendimento dos usuários dos serviços de saúde, especialmente das mulheres portadoras do HIV, para que haja a construção do vínculo e o estabelecimento da confiança na relação entre a equipe de PSF e a mulher HIV/AIDS. Com isso, a usuária sente-se segura em abrir sua privacidade para o profissional. As informações que fazem parte da privacidade da mulher podem auxiliar o planejamento das ações pertinentes às necessidades de saúde da usuária, sendo ela co-participante deste planejamento.

Nas situações descritas pelos membros das equipes, pôde-se apreender que são várias as definições que estes dão ao acolhimento. Entende-se que é necessário discutir nas equipes o sentido dado a acolhimento, as formas de sua expressão, as formas de operacionalizá-lo pelos membros da equipe, mas mais do que isso, buscar identificar, com as usuárias suas necessidades em relação ao acolhimento.

Conforme se destacou, o vínculo estabelecido com a família é condição para o desenvolvimento das ações no PSF. No entanto, segundo as falas dos sujeitos da pesquisa não está muito claro o significado do que seja vínculo. Concordam que é necessário tempo e paciência, que as visitas domiciliárias são fundamentais para a sua construção e que há o sentimento de proximidade com as famílias. No entanto, não está clara a existência ou não de limite para o estabelecimento do vínculo. Identificou-se que há o envolvimento dos profissionais nas situações, trazendo muitas vezes sentimentos como sofrimento, gerando desgaste dos profissionais. Estas são questões que devem ser abordadas nas equipes.

No vínculo entre as famílias, seus indivíduos e as equipes de PSF, quando se há confiança, a usuária pode abrir a privacidade das informações sobre seu diagnóstico de HIV/AIDS. Das falas apreendeu-se que o profissional deve inicialmente discutir com ela o estabelecimento de um acordo, no qual, as informações reveladas serão mantidas em segredo entre os profissionais. A garantia 
da confidencialidade das informações é essencial para a manutenção do relacionamento do profissional e a usuária.

Neste acordo é importante que se discuta com a usuária quais informações podem ser compartilhadas com os membros da equipe, quais vão ser mantidas em sigilo por todos e que a usuária acolhida quanto às suas necessidades.

Relacionado ao tema a revelação do diagnóstico de HIV aos membros da equipe de PSF, mostrou que o ACS é um dos profissionais que mais próximo está das questões que envolvem a privacidade e o sigilo das informações. No entanto, apreendeu-se das falas que muitas vezes este se encontra em situações de difícil abordagem, não sabendo muito como proceder, principalmente nos casos em que a usuária não sabe que ele conhece o seu diagnóstico. O estímulo para a abertura da privacidade pode contribuir para uma discussão mais franca, auxiliando na realização das ações.

A informação sobre o diagnóstico de membros das famílias sob a responsabilidade das equipes de PSF chegou por outras fontes que não só pelo exame realizado pela própria equipe e pela abertura da privacidade da usuária. Ela foi feita também pelos familiares, amigos e vizinhos. Cabe a equipe discutir o contexto de cada família, o significado desta informação, as condutas a partir do conhecimento desta informação. A princípio, se a própria usuária não abriu a privacidade desta informação à equipe, deve ser buscado estratégias para que ela própria o faça.

Outra forma importante de conhecimento do diagnóstico de HIV de mulheres na área de abrangência das equipes se deu pelo serviço de referência da região. Neste aspecto, considera-se importante que haja a comunicação entre estes e os de PSF, desde que sejam tomadas medidas que assegurem a confidencialidade desta informação. Neste sentido, são necessários também cuidados em relação ao envio de resultados de exames sorológicos e na manipulação dos prontuários Concorda-se que é necessário o uso das informações eletrônicas para que, mesmo os funcionários do serviço de saúde, não possam acessar informações sigilosas dos usuários sem que exista clara necessidade em benefício do usuário.

No tema discussão em equipe e o sigilo das informações, destacou-se que a discussão em equipe é um diferencial no PSF, oportunidade em que há o compartilhamento das necessidades de saúde identificadas e o planejamento conjunto 
das ações. Desta forma, há o compartilhamento da informação sobre o diagnóstico de HIV/AIDS entre os membros da equipe, sendo discutido o seu caráter sigiloso. Conforme já se discutiu, é preciso criar condições para que a usuária autorize o compartilhamento das informações do seu diagnóstico. Neste momento é importante que o profissional esclareça sobre o processo de trabalho das equipes de PSF.

Algumas situações devem ser ponderadas em relação ao compartilhamento da informação sobre o diagnóstico numa discussão em equipe, por exemplo, quando se considera que esta informação de fato pode contribuir no planejamento das ações e que este pode ser feito com o auxílio de outros membros da equipe.

O fato de ter o profissional ACS, sendo ele membro da comunidade traz implicações sobre a preservação do sigilo e confidencialidade das informações, conforme se discutiu. Portanto, no interior das equipes estas são situações que devem ser discutidas, especialmente em relação às formas de abordar as famílias, as formas de garantir a manutenção do sigilo, as dificuldades para a construção de vínculos e do estabelecimento de confiança, as formas de acolhimento das necessidades de saúde das famílias, etc.

Diante do exposto, conclui-se que o PSF pode incluir ações voltadas às mulheres portadoras do HIV/AIDS e que a abertura da privacidade pela usuária pode auxiliar na resposta às necessidades de saúde pelas equipes de PSF. As ações de acolhimento no fortalecimento do vínculo e no estabelecimento da confiança são processos fundamentais para que ocorra a abertura da privacidade. Ao mesmo tempo, cabe aos profissionais de saúde do PSF desenvolver habilidades e mecanismos que possam garantir a confidencialidade e o sigilo das informações.

Não se pretende no presente estudo fazer generalizações, no entanto, esperase que a partir da análise das situações descritas sobre privacidade e sigilo permita-se subsidiar a discussão para a melhoria da qualidade de assistência nos diferentes cenários de atuação do PSF. 


\section{REFERÊNCIAS BIBLIOGRÁFICAS}

1. Almeida M, Romero Munoz D. Relação médico-paciente e pacienteinstituição na AIDS: o direito á informação e a confidência, a discriminação e a coerção. Bioética. 1993;1(1):49-53.

2. Boletim epidemiológico da AIDS.Ministério da Saúde. Brasília 2000;13(1).

3. Boletim HIV/ AIDS: Ministério da Saúde. Brasília Ano II $n^{\circ} 01-1^{\mathrm{a}}$ a $26^{\mathrm{a}}$ semanas epidemiológicas; jan-jun, 2005; dezembro - www.AIDS.gov.br.

4. Bardin L. Análise de conteúdo. Lisboa: Edições 70; 1995.

5. Boletim Epidemiológico da HIV/AIDS, DST, hepatites B e C do Município de São Paulo; 2006.

6. Boletim Epidemiológico de Aids/HIV, DST, hepatites B e C do Município de São Paulo. Setembro, 2004.

7. Boletim Epidemiológico: Aids e DST. Ministério da Saúde. Brasília , 2006; $1^{\mathrm{a}}-26^{\mathrm{a}}$ semanas epidemiológicas; jan-jun; 3(1).

8. Boletim Epidemiológico: Ministério da Saúde. Brasília Aids e DST - $1^{\mathrm{a}}$ 52 ${ }^{\mathrm{a}}$ semanas epidemiológicas; Ano XVII, nº 01; 2003

9. Brasil. Ministério da Saúde. Aconselhamento em DST, HIV e Aids: diretrizes e procedimentos básicos. $3^{\text {a }}$ ed. Brasília; 1999.

10. Brasil. Ministério da Saúde. Epidemiologia e serviços de saúde. Rev Sistema Único Saúde. 2005;14(2):

11. Brasil. Ministério da Saúde. Gestão em saúde: instrumentos de gestão do SUS. Brasília; 2001.

12. Brasil. Ministério da Saúde. Recomendações para prevenção da transmissão do HIV em instituições de Saúde. Brasília; 1997.

13. Bueno FS. Grande dicionário etimológico-prosaico da língua portuguesa: vocábulos, expressões da língua geral e científica - sinônimos, contribuições tupi-guarani. São Paulo: Saraiva; 1963.

14. Bueno WS, Merhy EE. A operacionalização das políticas públicas da saúde no âmbito da gestão e da assistência: o SUS, suas normas operacionais e os modelos assistenciais. São Paulo; 1997.

15. Czeresnia D. Do contágio à transmissão: ciência e cultura na gênese do conhecimento epidemiológico. Rio de Janeiro: FIOCRUZ; 1997. 
16. D’Amélio R, Tuerlings E, Perito O, Biselli R, Natalicchio S, Kingma S. A global review of legislation on HIV/AIDS: the issue of HIV testing. J Acquir Immune Defic Syndr. 2001;28:173-9.

17. David R. A vulnerabilidade ao adoecimento e morte por aids em usuários de um serviço ambulatorial especializado em DST/AIDS do município de São Paulo [dissertação]. São Paulo: Escola de Enfermagem, Universidade de São Paulo; 2002.

18. Ferraz AF. Aprender a viver de novo a singularidade da experiência de tornar-se portador do HIV e doente com aids [tese]. São Paulo: Escola de Enfermagem,Universidade de São Paulo; 1998.

19. Ferreira FC. As condições que levam as mulheres soropositivas ao HIV/AIDS a abrir sua privacidade de suas informações às equipes do Programa Saúde da Família [dissertação]. São Paulo: Escola de Enfermagem, Universidade de São Paulo; 2007.

20. Ferreira MPS, Silva CMFP, Gomes MCF, Silva SMB. Testagem sorológica para o HIV e a importância dos Centros de Testagem e Aconselhamento (CTA): resultados de uma pesquisa no município do Rio de Janeiro. Ciên Saúde Coletiva. 2001;6(2):481-90.

21. Figueiras SL, Deslandes SF. Avaliação das ações de aconselhamento: análise de uma pespectiva de prevenção centrada na pessoa. Cad Saúde Pública. 1999;15 Supl 2:121-31.

22. Figueiredo MAC, Coelho WF. Atitudes frente á Síndrome da Imunodeficiência Adquirida (SIDA) e o atendimento domiciliar do paciente. DST J Bras Doenças Sex Transm 1996; 8(1):29-37.

23. Fortes PAC, Spinetti SR. O agente comunitário de saúde e a privacidade das informações dos usuários. Cad Saúde Pública. 2004;20(5):1328-33.

24. Fortes PAC, Zoboli ELCP, organizadores. Bioética e Saúde Pública. São Paulo: Centro Universitário São Camilo; 2003.

25. Fundação IBGE. Censo Demográfico. Rio de Janeiro; 2000.

26. Galvão MTG, Cerqueira ATAR, Marcondes MJ. Avaliação da qualidade de vida de mulheres com HIV/AIDS através do HAT-QoL. Cad Saúde Pública. 2004a;20(2):430-7.

27. Galvão MTG, Cerqueira ATAR, Marcondes MJ. Medidas contraceptivas e de proteção da transmissão do HIV por mulheres com HIV/AIDS. Rev Saúde Pública. 2004;38(2):194-200. 
28. Garcia-Sanchez I. Diferenciais de gênero en el VIH/sida. Gac Sanit. 2004;18(Supl 2):47-54.

29. Gomes MCPA, Pinheiro R. Acolhimento e vínculo: práticas de integralidade na gestão do cuidado em saúde em grandes centros urbanos. Interface. 2005;9(17):287-301.

30. Gryschek ALFPL. A política de qualificação da força de trabalho em enfermagem no programa municipal de DST/AIDS de São Paulo: um desafio contínuo [doutorado]. São Paulo: Escola de Enfermagem, Universidade de São Paulo; 2001.

31. Guerra MAT. Política de controle da Aids da Secretaria do Estado da Saúde no período de 1983-1992: a história contada por seus agentes [dissertação]. São Paulo: Faculdade de Medicina, Universidade de São Paulo; 1993.

32. Link BG, Phelan JC. Conceptualizing stigma. Annu Rev Sociol. 2001; 21:363-85.

33. Longa PARRC. A trajetória do portador HIV: da suspeita da infecção à assistência [dissertação]. São Paulo: Escola de Enfermagem, Universidade de São Paulo; 1999.

34. Lopes MV, Fraga MVO. Pessoas vivendo com HIV: estresse e suas formas de enfrentamento. Rev Lat Am Enferm. 1998;6(4):75-81.

35. Manual de Vigilância Epidemiológica: Síndrome da Imunodeficiência Adquirida, normas e instruções. São Paulo; 1995.

36. Massarollo MKB, Sacardo DP, Zoboli ELCP. Autonomia, privacidade e confidencialidade. In: Oguisso T, Zoboli ELCP, organizadores. Ética e bioética: desafios para a enfermagem e a saúde. São Paulo: Manolle; 2006. p.136-52.

37. Matumoto SO. Acolhimento: um estudo sobre seus componentes e sua produção em uma unidade da rede básica de serviços de saúde [dissertação]. Ribeirão Preto: Escola de Enfermagem de Ribeirão Preto, Universidade de São Paulo; 1998.

38. Merhy EE. Em busca da qualidade dos serviços de saúde: os serviços de portas abertas para a saúde e o modelo tecno-assistencial em defesa da vida. In: Cecílio LCO (org). Inventando a mudança na saúde. São Paulo; Huctec; 138p.

39. Minayo MCS. O desafio do conhecimento: pesquisa qualitativa em saúde. $8^{a}$ ed. São Paulo: Hucitec; 2004. 
40. Miranda SD. Estudo comparativo da flora microbiana cérvico-vaginal e outras variáveis da rotina ginecológica em mulheres infectadas e não infectadas pelo vírus da imunodeficiência humana [dissertação]. São Paulo: Faculdade de Medicina, Universidade de São Paulo; 1996.

41. Neves FRA. O aconselhamento para a realização da sorologia anti-HIV em gestantes: factibilidade e utopias. [dissertação]. Ribeirão Preto. Escola de Enfermage, Universidade de São Paulo; 2003; 134p.

42. Nichiata LYI. Epidemiologia da AIDS: Os (des) caminhos da informação [dissertação]. - São Paulo: Escola de Enfermagem, Universidade de São Paulo; 1995.

43. Paiva V. O simbolismo da aids, alteridade e cidadania. In: Paiva V, organizador. Em tempos da aids. São Paulo: SUMMUS; 1992. p.53-62.

44. Parker R, Aggleton P. HIV and AIDS-related stigma and discrimination: a conceptual framework and a implications for action. Rio de Janeiro: Associação Brasileira Interdisciplinar de AIDS; 2002.

45. Parker R, Camargo JR. Pobreza e HIV/AIDS: aspectos antropológicos e sociológicos. Cad Saúde Pública. 2000;16(1):89-102.

46. Pereira MLD. A (re) invenção da sexualidade feminina após a infecção do HIV [tese]. São Paulo: Escola de Enfermagem, Universidade de São Paulo; 2001. 129p.

47. Pessini L, Barchifontaine CP. Bioética: do principalismo à busca de uma perspectiva latino-americana. In: Costa SIF, Garrafa V, Oselka G, coordenadores. Iniciação à Bioética. Brasília: Conselho Federal de Medicina; 1998. p.81-98.

48. Pessini L, Barchifontaine CP. Problemas atuais da bioética. $5^{a}$ ed. São Paulo: Loyola; 2000.

49. Reis RK. Convivendo com a diferença: o impacto da sorodiscordância na vida afetivo-sexual de portadores HIV/ AIDS [dissertação]. Ribeirão Preto: Escola de Enfermagem de Ribeirão Preto, Universidade de São Paulo; 2004.

50. Ritcher M. Preliminary assumptions on the nature and extent of discrimination against people living with aids in South África - Interviews and a sutdy of Aids Law project client files 1993-2001. Soth Africa: AIDS Law project [homepage na Internet]. 2001 [cited 2003 ago. 18]. Available from: http:www.alp.org.za/resctr/rpaprs/misc/200110731_rpmrnaead.doc.

51. Sacardo DP. Expectativa de privacidade segundo pessoas hospitalizadas e não hospitalizadas: um estudo bioético [mestrado]. São Paulo: Faculdade de Saúde Pública; Universidade de São Paulo; 2001. 
52. Sacardo DP, Fortes PAC. Desafios para a preservação da privacidade no contexto da saúde. Bioética; 2000; 8(2): 307-22.

53. Santos NJS, Tayra A, Silva SR, Buchalla CM, Laurenti R. A aids no estado de São Paulo: as mudanças no perfil da epidemia e perspectivas da vigilância epidemiológica. Rev Bras Epidemiol. 2002;5(3).

54. São Paulo. Secretaria de Estado da Saúde. Coordenação dos Institutos de Pesquisa. Ações de prevenção e assistência as DST/AIDS na rede de atenção básica à saúde do estado de São Paulo; 2003.

55. Selli L. Bioética na enfermagem. São Paulo: Unisinos; 1999.

56. Silva LMS, Guimarães TA, Pereira MLD, Miranda KCL, Oliveira EM. Integralidade em saúde: avaliando a articulação e a co-responsabilidade entre o Programa de Saúde da Família e um serviço de referência em HIV/ AIDS. Epidemiol Serviços Saúde. 2005;14(2): 97-104.

57. Silva JÁ. Dalmalso ASW. O agente comunitário de saúde e suas atribuições: os desafios para os processos de formação de recursos humanos em saúde. Rev. Interface- Comuni, Saúde, Educ; 2002; 6(10); p.75-96.

58. Silveira EAA, Carvalho, AMP. Familiares de clientes acometidos pelo HIV/AIDS e o atendimento prestado em uma unidade ambulatorial. Rev Lat Am Enferm. 2002;10(6):813-8.

59. Sontag S. AIDS e suas metáforas. São Paulo: Companhia das Letras; 1989.

60. Souza SPS. A inserção do médico no serviço público de saúde: um olhar focalizado no Programa de Saúde da Família [dissertação]. Rio de Janeiro: Instituto de Medicina Social; 2001.

61. Takahashi RF, Gir E, Gryschek ALFPL, Nichiata LYI. Assistência de enfermagem na infecção pelo HIV: diagnóstico situacional. In: Resumos do $50^{\circ}$ Congresso Brasileiro de Enfermagem; 1998; Salvador. Salvador: ABENSeção- BA; 1999. p.179.

62. Teixeira P. Universal care for patients with SIDA. In: Souza CR, Menezes L. AIDS, the epidemic in megacities: networking the response. São Paulo; 2002. p. 221-31.

63. Tunala LG. Fontes cotidianas de estresse em mulheres portadoras do HIV. Rev Saúde Publica. 2002;36(4 Supl): 24-31.

64. Turienzo G, Mesquita F. Um panorama da luta contra a epidemia de DST/AIDS na cidade de São Paulo. In: Mesquita F, Souza CR, 
organizadores. DST/AIDS: a nova cara da luta contra a epidemia na cidade de São Paulo. São Paulo: Raiz da Terra; 2003. p.13-7.

65. Villela W. Oficinas de sexo mais seguro para mulheres: abordagens metodológicas e de avaliação. São Paulo: Nepaids; 1996.

66. Zoboli ELCP, Fortes PAC. Bioética e atenção básica: um perfil dos problemas éticos vividos por enfermeiros e médicos do Programa Saúde da Família, São Paulo, Brasil. Cad Saúde Pública. 2004;20(6):1690-9.

67. Zoboli ELCP. Bioética e atenção básica: um estudo de ética descritiva com enfermeiros e médicos do Programa Saúde da Família [doutorado]. São Paulo: Faculdade de Saúde Pública, Universidade de São Paulo; 2003.

68. Zoboli ELCP. Bioética: gênese, conceituação e enfoques. In: Ogisso T, Zoboli ELCP, organizadores. Ética e bioética: desafios para a enfermagem e a saúde. São Paulo: Manolle; 2006. 


\section{ANEXOS \\ ANEXO 01 \\ TERMO DE CONSENTIMENTO E LIVRE ESCLARECIMENTO}

Meu nome é Fernanda Tavares de Mello Abdalla. Sou aluna do Programa de Pós-Graduação da Escola de Enfermagem da USP, e estou desenvolvendo um projeto de pesquisa que tem como objetivo contribuir para a melhoria da assistência prestada aos indivíduos portadores de HIV/AIDS no modelo assistencial de atenção básica do Programa Saúde da Família.

As entrevistas serão realizadas individualmente e serão gravadas em fitas cassete. O conteúdo dessas entrevistas e quaisquer informações fornecidas serão utilizados apenas para a realização do estudo. O nome do entrevistado não será revelado e as informações não lhe causarão nenhum prejuízo em relação ao seu trabalho aqui na unidade. Por favor, fique à vontade para decidir se quer ou não participar. Se concordar, sua participação será muito bem-vinda e importante. Os resultados deste estudo serão divulgados para o conhecimento dos profissionais de saúde tanto em eventos científicos, quanto em publicações da área de saúde.

Há alguma dúvida que eu possa esclarecer?

Caso venha a ter dúvidas, estou disponível nos contatos:

Tel: (011) 81816047

e-mail: feabdalla@yahoo.com.br

Fernanda Tavares de Mello Abdalla

Caso tenha dúvidas, queira maiores esclarecimentos, ou reclamar sobre os procedimentos éticos deste estudo, pode entrar em contato com o Comitê de Ética em Pesquisa da Secretaria Municipal de Saúde de São Paulo, na Rua General Jardim, 36, 2o andar. Fone: 3218-4043. E-mail: smscep@prefeitura.sp.gov.br 


\section{TERMO DE CONSENTIMENTO LIVRE E ESCLARECIDO}

Declaro que estou esclarecido quanto aos propósitos e objetivos do projeto de pesquisa "O Enfrentamento das necessidades de saúde das mulheres portadoras do HIV/AIDS pelo Programa Saúde da Família numa Unidade Básica de Saúde do município de São Paulo”, e concordo em participar da coleta de dados desse estudo. Estou consciente que o conteúdo dessas entrevistas e quaisquer informações fornecidas serão utilizadas apenas para a realização do estudo. Sei que meu nome não será revelado e as informações não causarão nenhum prejuízo em relação ao meu trabalho aqui na unidade.

Assinatura do Pesquisado

Fernanda Tavares de Mello Abdalla

DATA: 


\section{ANEXO 02 \\ CARCATERIZAÇÃO DOS ACS E ROTEIRO DO GRUPO FOCAL}

Caracterização do Agente Comunitário de Saúde

NOME

SEXO

( ) F ( )M

IDADE

TEMPO DE TRABALHO COMO ACS NA UBS VILA PENTEADO

\section{PARTICIPAÇÃO EM CAPACITAÇÕES NA TEMÁTICA DA AIDS}

( ) SIM ( ) NÃO

Roteiro de questões norteadoras a ser aplicado no Grupo Focal (Agente Comunitário de Saúde)

1- Na comunidade atendida por vocês, existem mulheres portadoras do HIV/AIDS? Descreva as condições sociais dessas mulheres e o relacionamento com as famílias.

2- Como vocês ficaram sabendo que essas mulheres têm HIV/AIDS?

3- Como se dá o relacionamento ACS e a mulher/usuária portadora do HIV/AIDS? E o relacionamento com a equipe? 
4- Como vocês identificam as necessidades das mulheres HIV/ aids?

5- O que vocês identificam como necessidade de saúde dessas mulheres? Do que vocês acham que essas mulheres necessitam?

6- Como vocês fazem o cuidado às mulheres HIV/AIDS? Relatem casos e experiências se possível.

7- Como a equipe de PSF consegue identificar e satisfazer as necessidades de saúde das mulheres com HIV/AIDS?

8- Contem um pouco sobre a questão do sigilo sobre o diagnóstico dessas mulheres. Como vocês lidam com isso na equipe e na comunidade?

9-As mulheres portadoras do HIV/AIDS são assistidas por outros serviços de saúde?

10- O que vocês acham que as mulheres HIV/AIDS precisam para estarem satisfeitas (felizes) com suas vidas? 


\section{ANEXO 03}

Roteiro de entrevista semi-estruturada junto aos profissionais de saúde da equipe de PSF (médico, enfermeiro, auxiliar de enfermagem).

Número do questionário:

Data:

Unidade Básica de Saúde:

Equipe de PSF:

Horário de início: Horário de término:

Duração:

\section{Caracterização do profissional:}

Sujeito entrevistado:

Categoria profissional:

Médico ( ) Enfermeiro ( ) Auxiliar de Enfermagem ( ) Agente Comunitário ( ) Idade: Sexo:

Formação acadêmica:

Pós-Graduação ( ) concluído ( ) em andamento ( )

Especialização ( ) concluído ( ) em andamento ( ) Qual?

Outro:

Tempo de trabalho na área da Saúde:

Tempo de trabalho no PSF:

Tempo de trabalho nesta UBS:

Recebeu alguma capacitação na temática da aids? Sim ( ) Não ( )

\section{Questões norteadoras}

1. O que a UBS oferece de recursos para as mulheres acometidas pelo HIV no âmbito da prevenção? 
2. Como se dá o sistema de referência e a contra-referência entre a UBS e o serviço especializado DST/AIDS?

3. Você conhece, na sua área de abrangência, alguma mulher que é acometida pelo HIV? Como você ficou sabendo?

4. Você já teve experiência de assistência no PSF com mulher acometida pelo HIV/AIDS? Como você ficou sabendo que ela era portadora do HIV?

5. O caso foi discutido na equipe?

6. Todos os membros da equipe ficaram sabendo do caso?

7. Como a equipe lidou com a questão do sigilo?

8. Quais as necessidades desta mulher que a equipe identificou?

9. Quais foram as ações planejadas pela equipe?

10. Quais das ações planejadas foram executadas?

11. Quais foram os resultados obtidos?

12. Quais foram as dificuldades encontradas pela equipe para a implementação dessas ações?

$\underline{\text { Roteiro de entrevista semi-estruturada junto aos profissionais de saúde da }}$ equipe de PSF (médico, enfermeiro e auxiliar de enfermagem).

\section{A) QUESTÕES DE CARACTERIZAÇÃO DO PROFISSIONAL.}

Partindo de exemplos de situações concretas vivenciadas no seu cotidiano de trabalho, fale um pouco sobre quais são seus principais valores e crenças sobre:

- A sua vida (o que você acredita serem coisas "boas” e coisas "ruins” projetos de felicidade, prazeres, tristezas, decepções). O que você considera como mais importante e menos importante na sua vida. Você tem projetos de felicidade, quais?

- A saúde: O que você acha que é saúde? O que se precisa para ter saúde? O que é “certo” e “errado” fazer para ter saúde? O que é importante na sua saúde hoje?

- A família: O que é família? O que acha que é “bom” e "ruim” na sua família? 
- O trabalho: Qual é a sua opinião sobre o seu trabalho aqui na UBS? Quais são os pontos positivos e os pontos negativos, o que é bom e o que é ruim? Com relação aos recursos materiais e os equipamentos sociais, quais são as facilidades e as dificuldades que você vive no seu trabalho? Você gosta do seu trabalho aqui na UBS?

- O trabalho: Descreva como você realiza um atendimento durante a rotina do seu trabalho (recursos, instrumentos, conteúdo, finalidade). Quais são as condutas que você toma frente aos casos?

- O PSF: O que você acha do PSF? Como e quando você acha que os princípios do PSF aparecem no dia-a-dia, na assistência que você presta? O PSF, em sua opinião, funciona para a sua população?

- A população: Descreva as características da população usuária da UBS (condições de vida, renda, escolaridade, cultura, condições de trabalho, condições de saúde).

\section{B) QUESTÕES SOBRE A AIDS E SEU ENFRENTAMENTO:}

Partindo de exemplos de situações concretas vividas no PSF do seu local de trabalho, fale um pouco sobre as práticas e as ações de saúde sobre:

- A Aids: Como você enxerga a epidemia da aids? Dê a sua opinião sobre a aids. Qual é o impacto que a aids gera na sua comunidade?

- A população portadora do HIV/AIDS: Descreva as características da população portadora do HIV/AIDS usuária da UBS (sexo, condições de vida, renda, escolaridade, cultura, condições de trabalho, condições de saúde).

- A população feminina portadora de HIV/AIDS: Descreva as características da população portadora do HIV/AIDS usuária da UBS (sexo, condições de vida, renda, escolaridade, cultura, condições de trabalho, condições de saúde).

- As necessidades de saúde: Em sua opinião, quais são as necessidades de saúde que as mulheres portadoras do HIV/AIDS têm? Como e quando você identifica essas necessidades? Fale sobre suas ações 
frente aos casos de mulheres portadoras do HIV/AIDS em situações de: acolhimento, consultas, visitas domiciliares, grupos, etc.

- A assistência de saúde/ o cuidado às mulheres portadoras do HIV/AIDS: Quais são as ações de saúde que você presta? Como você responde as necessidades de saúde? Como você realiza o cuidado? Como você enfrenta essa demanda?

- O Acolhimento: como são feitas as ações de acolhimento às mulheres HIV/AIDS? Descreva alguns episódios se possível (local atividade...).

- O vínculo: Como você se relaciona com as mulheres portadoras do HIV/AIDS da sua comunidade? Fale um pouco sobre o seu relacionamento profissional com a usuária.

- O sigilo profissional: Como você fica sabendo sobre a infecção do HIV? Como é discutido o caso? Como você aborda a questão do sigilo com a usuária? Como é abordada a questão do acometimento do HIV/AIDS por você com relação aos outros profissionais? 